\title{
NPK-lannoituksen vaikutus Pito-perunan ravinteiden ottoon
}

\author{
EERO VARIS \\ Hankkijan kasvinjalostuslaitos, Anttilan koetila, Hyrylä
}

Saapunut 29.10.1973

\section{The effects of increased amounts of $N, P$, and $K$ on the nutrient uptake of Pito potato}

\author{
EERo VARIS \\ Plant Breeding Institute of Hankkija, Experimental Farm Anttila, Hyrylä, Finland
}

\begin{abstract}
The effects of $\mathrm{N}$ rates of 0,100 and 200, $\mathrm{P}$ rates of 0,87 and 174 and $\mathrm{K}$ rates of 0,166 and $332 \mathrm{~kg} / \mathrm{ha}$ on the nutrient uptake of Pito potato was studied in 1967, 1968 and 1970.

The highest yield of tuber dry matter, $5793 \mathrm{~kg} / \mathrm{ha}$, was obtained at the $\mathrm{N}_{1} \mathrm{P}_{2}$ level, the effect of $\mathrm{K}$ being insignificant. The corresponding total dry matter yield was 8016 $\mathrm{kg} / \mathrm{ha}$. In this case, the total uptakes of nutrients were $(\mathrm{kg} / \mathrm{ha}) 129 \mathrm{~N}, 15 \mathrm{P}, 230 \mathrm{~K}, 42$ $\mathrm{Ca}$ and $19 \mathrm{Mg}$. Corresponding uptakes in the tubers were $75 \mathrm{~N}, 11 \mathrm{P}, 122 \mathrm{~K}, 2.2 \mathrm{Ca}$ and $6 \mathrm{Mg}$.

$\mathrm{N}$ application increased the $\mathrm{N}$ uptake by increasing the dry matter yield and improving the $\mathrm{N}$ content of the haulms and the tubers. The effect was more pronounced in the case of the haulms. Uptakes of $\mathrm{P}, \mathrm{K}, \mathrm{Ca}$ and $\mathrm{Mg}$ also increased. The relative uptake of $\mathrm{P}$ and $\mathrm{Mg}$ decreased, however, and their transfer into tubers was delayed. The $\mathrm{K}$ content of the haulms increased, their $\mathrm{Ca}$ content decreased.

$\mathrm{P}$ application increased the uptake of $\mathrm{N}, \mathrm{K}, \mathrm{Ca}$ and $\mathrm{Mg}$ in accordance with the increase of dry matter. The transfer of $\mathrm{N}$ and $\mathrm{Ca}$ into the tubers was accelerated, that of $\mathrm{K}$ retarded by the end of the growing period.

$\mathrm{K}$ application had no significant effect on the uptake of $\mathrm{N}, \mathrm{P}$, or $\mathrm{K}$. However, the uptake of $\mathrm{P}$ was retarded by a heavy $\mathrm{KN}$ application. The uptake of Ca showed an insignificant decreasing trend. The uptake of $\mathrm{Mg}$ and the $\mathrm{Mg}$ content of the haulms decreased somewhat. The $\mathrm{K}$ content of the haulms and also of the tubers was improved.
\end{abstract}

Perunan ravinteiden otosta on runsaasti kirjallisuustietoja. Suomessa on perunan ravinteiden ottoa tutkinut TuORILA (1929). Hänen saamiensa tulosten mukaan $25.000 \mathrm{~kg}: \mathrm{n}$ perunasato ja siihen kuuluva $8.000 \mathrm{~kg}: \mathrm{n}$ varsisato tarvitsevat $104 \mathrm{~kg} \mathrm{~N}, 17 \mathrm{~kg}$ P, $143 \mathrm{~kg} \mathrm{~K}$ ja 49 kg Ca hehtaaria kohti. Suomalaisissa perunanviljelyoppaissa mainitaan vastaavasti seuraavia ravinnemääriä 25.000-28.000 kg:n perunasadolle $(\mathrm{kg} / \mathrm{ha})$ : 


\begin{tabular}{|c|c|c|c|c|}
\hline & $\begin{array}{l}\text { SaULi } \\
(1943)\end{array}$ & $\begin{array}{l}\text { SALONEN } \\
\text { (1962) }\end{array}$ & $\begin{array}{c}\text { SEPPÄNEN ja VARIS } \\
\text { (1969) }\end{array}$ & $\begin{array}{c}\text { Ellala ym. } \\
\text { (1971) }\end{array}$ \\
\hline .................... & 104 & 120 & 140 & $120-150$ \\
\hline $\mathrm{P}$ & $17-21$ & 18 & 20 & $20-30$ \\
\hline 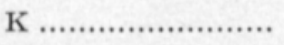 & $143-181$ & 141 & 208 & $170-240$ \\
\hline $\mathrm{Ca}$ & $49-51$ & 14 & 57 & $50-70$ \\
\hline $\mathrm{Mg}$ & - & - & - & 30 \\
\hline
\end{tabular}

Ruotsissa käytettyjen ohjearvojen mukaan $30.000 \mathrm{~kg}$ :n perunasato tarvitsee $(\mathrm{kg} / \mathrm{ha})$ :

\begin{tabular}{|c|c|c|}
\hline & $\begin{array}{c}\text { DJURLE } \\
(1939)\end{array}$ & $\begin{array}{c}\text { EMILSson ym. } \\
(1968)\end{array}$ \\
\hline N & 145 & 160 \\
\hline P & 29 & 27 \\
\hline 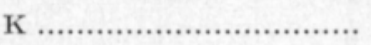 & 257 & 226 \\
\hline 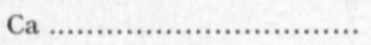 & - & 64 \\
\hline 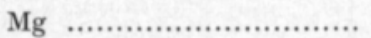 & - & 29 \\
\hline
\end{tabular}

Saksalaisten tutkimusten mukaan, joita ovat referoineet mm. LÜDDECKE ja Borchmann (1961), $10.000 \mathrm{~kg}: \mathrm{n}$ perunasato tarvitsee varsineen ( $\mathrm{kg} / \mathrm{ha}$ ) $44-55 \mathrm{~N}, 9-10 \mathrm{P}, 66-83 \mathrm{~K}$ ja $18-25 \mathrm{Ca}$. Lisäksi $20.000 \mathrm{~kg}$ :n perunasato tarvitsee $15 \mathrm{~kg} / \mathrm{ha} \mathrm{Mg}$. Uusimmassa saksalaisessa perunakirjallisuudessa käytetään ohjelukuina $30.000 \mathrm{~kg}$ :n perunasadolle seuraavia ravinnemääriä $(\mathrm{kg} / \mathrm{ha})$ : $150 \mathrm{~N}, 26 \mathrm{P}, 199 \mathrm{~K}, 64 \mathrm{Ca}$ ja $17 \mathrm{Mg}$ (Hunnius 1972).

Amerikkalaisten tutkimusten mukaan, joita on referoinut mm. BENEPAL (1967) hyvä perunasato käyttää (kg/ha) $120-160 \mathrm{~N}, 11-13 \mathrm{P}, 166-208 \mathrm{~K}$, $43 \mathrm{Ca}$ ja $17 \mathrm{Mg}$.

Selostettavassa tutkimuksessa haluttiin verrata Pito-perunan ottamia ravinnemääriä aikaisempiin tutkimustuloksiin ja samalla selvittää ravinnesuhteiden muutosten vaikutusta eri ravinteiden ottoon.

\section{Koeaineisto ja tulosten käsittely}

Tämä tutkimus perustuu Hankkijan kasvinjalostuslaitoksen Anttilan koetilalla vuosina $1967-68$ ja 1970 tehdyn tutkimuksen aineistoon, joka on selvitetty aikaisemmin (VARIS 1973 b).

\section{Tulokset ja niiden tarkastelu}

Varsianssianalyysien antamat tulokseț on esitetty Taulukossa 1. Tulosten tarkemmassa käsittelyssä sivuutetaan maininnalla suurin osa vuosivaihteluista (A ja yhdysvaikutukset), mitkä tämän tyyppisissä tutkimuksissa ovat sangen yleisiä. Joskus suotuisissa kasvuoloissa vuosivaihtelu tosin voi jäädä merkityksettömäksi (CARPENTER 1957). Tässä tutkimuksessa vuosivaihtelu oli selvästi yleisintä ja merkitsevintä typen suhteen (AN ja 2. asteen yhdysvaikutukset), kun taas fosforin ja varsinkin kaliumin osalta vuosivaihtelu oli vähäisempää sekä perunan ravinteiden otossa että sadon mineraalipitoisuuksissa. 
Taulukko 1. Varsianssianalyysi NPK-lannoituksen vaikutuksesta Pito-perunan ravinteiden ottoon kasvukausina 1967, 1968 ja 1970.

Table 1. Analysis of variance of the effects of NPK treatments on nutrient uptake by Pito potato during the growing periods of 1967, 1968 and 1970.

\begin{tabular}{|c|c|c|c|c|c|c|c|c|c|c|c|c|}
\hline \multirow{3}{*}{$\overline{\left.A^{1}\right)}$} & & \multirow{2}{*}{$\begin{array}{c}\text { Kuiva- } \\
\text { aine } \\
\text { Dry } \\
\text { malter } \\
\mathrm{kg} / \mathrm{ha}\end{array}$} & \multicolumn{2}{|l|}{$\mathrm{N}$} & \multicolumn{2}{|c|}{$\mathrm{P}$} & \multicolumn{2}{|c|}{$\mathrm{K}$} & \multicolumn{2}{|c|}{$\mathrm{Ca}$} & \multicolumn{2}{|c|}{$\mathrm{Mg}$} \\
\hline & & & $\begin{array}{c}\% \\
\text { ka:ssa } \\
\text { in D.M. }\end{array}$ & $\mathrm{kg} / \mathrm{ha}$ & $\begin{array}{c}\% \\
\text { ka:ssa } \\
\text { in D.M. }\end{array}$ & $\mathrm{kg} / \mathrm{ha}$ & $\begin{array}{c}\% \\
\text { ka:ssa } \\
\text { in D.M. }\end{array}$ & $\mathrm{kg} / \mathrm{ha}$ & $\begin{array}{c}\% \\
\text { ka:ssa } \\
\text { in D.M. }\end{array}$ & $\mathrm{kg} / \mathrm{ha}$ & $\begin{array}{c}\% \\
\text { ka:ssa } \\
\text { in D.M. }\end{array}$ & $\mathrm{kg} / \mathrm{ha}$ \\
\hline & & $* * *$ & $* * *$ & $* * *$ & $* * *$ & $* * *$ & $* * *$ & $* * *$ & $* * *$ & $* * *$ & $* * *$ & $* * *$ \\
\hline $\mathrm{B}^{2}$ ) & & $* * *$ & $* * *$ & $* * *$ & $* * *$ & $* * *$ & $* * *$ & $* * *$ & $* * *$ & $* * *$ & * & $* * *$ \\
\hline$\left.C^{3}\right)$ & & $* * *$ & $* * *$ & $* * *$ & $* * *$ & $* * *$ & $* * *$ & $* * *$ & $* * *$ & $* * *$ & $* * *$ & $* * *$ \\
\hline $\mathrm{N}$ & & $* * *$ & $* * *$ & $* * *$ & $* * *$ & $* * *$ & $(*)$ & $* * *$ & $* * *$ & $* * *$ & ns & $* * *$ \\
\hline$P$ & & $*$ & ns & $* * *$ & $* * *$ & $* * *$ & $\mathrm{~ns}$ & $* * *$ & $\mathrm{~ns}$ & $* * *$ & ns & $* * *$ \\
\hline $\mathrm{K}$ & & ns & ns & ns & ns & ns & $* * *$ & ns & $* *$ & ns & $*$ & ns \\
\hline $\mathrm{AB}$ & & $* * *$ & $* * *$ & $* * *$ & $* * *$ & $* * *$ & $* * *$ & $* * *$ & $* * *$ & $* * *$ & $* * *$ & $* *$ \\
\hline $\mathrm{AC}$ & & $* * *$ & $* * *$ & $* * *$ & $* * *$ & $* * *$ & $* * *$ & $* * *$ & $* * *$ & $* * *$ & $* * *$ & $* * *$ \\
\hline AN & & $* * *$ & $* *$ & $* * *$ & $* * *$ & $* * *$ & $* * *$ & $* * *$ & $* * *$ & * & ns & $* * *$ \\
\hline AP & & ns & $(*)$ & $* *$ & $* * *$ & ns & ns & ns & $*$ & $*$ & ns & $\left({ }^{*}\right)$ \\
\hline AK & & ns & ns & ns & ns & ns & $\left({ }^{*}\right)$ & ns & ns & ns & ns & ns \\
\hline $\mathrm{BC}$ & & $* * *$ & $* * *$ & $* * *$ & $* * *$ & $* * *$ & $* * *$ & $* * *$ & $* * *$ & $* * *$ & $* * *$ & $* * *$ \\
\hline $\mathrm{BN}$ & & $* *$ & $* *$ & $* * *$ & $*$ & ns & ns & $* *$ & ns & ns & ns & $* * *$ \\
\hline BP & 13 & ns & ns & ns & $*$ & $*$ & ns & ns & $(*)$ & ns & ns & ns \\
\hline BK & & ns & ns & ns & ns & ns & ns & ns & ns & ns & ns & ns \\
\hline $\mathrm{CN}$ & & $* * *$ & $* * *$ & $* * *$ & $(*)$ & $* * *$ & $*$ & $* * *$ & $* * *$ & $* * *$ & $* *$ & $* * *$ \\
\hline $\mathrm{CP}$ & & ns & ns & ns & ns & $\left({ }^{*}\right)$ & * & $*$ & ns & $* * *$ & ns & $* *$ \\
\hline CK & & ns & ns & ns & ns & ns & $* *$ & $\mathrm{~ns}$ & $* * *$ & $* *$ & $* * *$ & $* *$ \\
\hline NP & & $(*)$ & ns & $* * *$ & $* *$ & $* * *$ & ns & $* * *$ & ns & $* *$ & ns & $* *$ \\
\hline NK & & ns & ns & ns & ns & $\mathrm{ns}$ & $* * *$ & ns & $(*)$ & ns & ns & ns \\
\hline PK & & ns & ns & $\mathrm{ns}$ & ns & ns & $\mathrm{ns}$ & $\mathrm{ns}$ & ns & ns & ns & ns \\
\hline $\mathrm{ABC}$ & & $* * *$ & $* * *$ & $* * *$ & $* * *$ & $* * *$ & $*$ & $* * *$ & $* * *$ & $* * *$ & $* * *$ & $* * *$ \\
\hline $\mathrm{ABN}$ & & $*$ & $* * *$ & $* * *$ & $* * *$ & $*$ & $* *$ & $(*)$ & $* *$ & * & $* * *$ & $* * *$ \\
\hline ABP & & ns & $* *$ & $* *$ & $* * *$ & $* *$ & ns & $* * *$ & ns & $* * *$ & ns & $* *$ \\
\hline ABK & & ns & ns & ns & ns & ns & $*$ & ns & ns & ns & ns & ns \\
\hline $\mathrm{ACN}$ & & $*$ & $* * *$ & $* * *$ & $* * *$ & $* * *$ & $* * *$ & $* * *$ & $* * *$ & $* * *$ & ns & $* * *$ \\
\hline $\mathrm{ACP}$ & & ns & ns & $*$ & ns & ns & ns & ns & $* *$ & $* *$ & $*$ & $* *$ \\
\hline $\mathrm{ACK}$ & & ns & ns & ns & $*$ & ns & $(*)$ & ns & $(*)$ & ns & $*$ & $*$ \\
\hline ANP & & $(*)$ & $*$ & $* * *$ & $* *$ & $* * *$ & ns & $* * *$ & ns & $* *$ & $*$ & $* * *$ \\
\hline ANK & & ns & $(*)$ & $(*)$ & ns & $*$ & $* *$ & $* *$ & ns & ns & ns & ns \\
\hline APK & & ns & $(*)$ & $*$ & ns & ns & $*$ & ns & ns & ns & $(*)$ & ns \\
\hline $\mathrm{BCN}$ & & $* *$ & * & $* * *$ & $*$ & $* * *$ & * & $* * *$ & $*$ & $*$ & $* * *$ & $* * *$ \\
\hline $\mathrm{BCP}$ & & $(*)$ & ns & $* *$ & $* *$ & $* * *$ & ns & ns & $* *$ & ns & ns & $\left(^{*}\right)$ \\
\hline BCK & $\because$ & $(*)$ & ns & ns & ns & ns & ns & ns & ns & ns & ns & ns \\
\hline BNP & & ns & ns & ns & ns & ns & ns & ns & ns & ns & ns & ns \\
\hline BNK & & ns & ns & ns & ns & ns & ns & ns & ns & ns & ns & ns \\
\hline BPK & & $*$ & ns & ns & ns & ns & ns & $* *$ & ns & $(*)$ & ns & $(*)$ \\
\hline CNP & & $(*)$ & $* *$ & ns & ns & $(*)$ & ns & $(*)$ & ns & $* * *$ & ns & $* *$ \\
\hline $\mathrm{CNK}^{2}$ & & ns & ns & ns & ns & ns & ns & ns & ns & ns & ns & ns \\
\hline NPK & & ns & $\mathrm{ns}$ & $* *$ & ns & * & ns & ns & ns & $(*)$ & ns & $*$ \\
\hline
\end{tabular}

1) $\mathrm{A}=$ vuosi, year

2) $\mathrm{B}=$ nostoaika, lifting time

3) $\mathrm{C}=1$ ehdet/mukulat, haulms/tubers 
Tulosten tarkastelun pohjaksi on otețtu saadut kuiva-ainesadot. Niihin vertaamalla on nimittäin helpointa seurata ravinteiden käyttöä, sillä ravinnemääräthän ovat kuiva-aineen määrän ja kuiva-aineen mineraalipitoisuuden funktioita.

Koko perunakasvin kuiva-ainesațo vaihteli vuosittain (A) ja lisääntyi tietenkin kasvukauden kuluessa (B). Syksyllä kuiva-ainesato kuitenkin aleni johtuen varsiston osittaisesta tuhoutumisesta hallan, tautien ym. syiden takia. Varsi- ja mukulasato olivat erilaiset (C) ja niiden suhde muuttui kasvukauden kuluessa (BC, Piirros 1). Kokonaiskuiva-ainesato oli suurimmillaan kolmannessa nostossa, kun taas mukuloiden kuiva-ainesato kasvoi syksyyn saakka. Vuotuiset vaihtelut olivat merkitsevät ( $\mathrm{AB}, \mathrm{AC}, \mathrm{ABC}$ ).

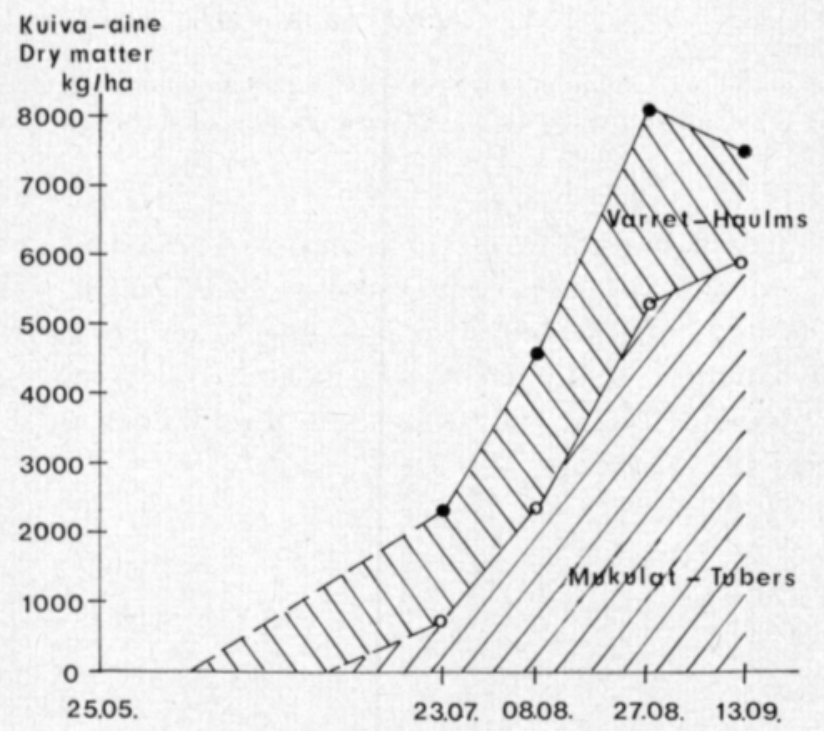

Piirros 1. Pito-perunan kuiva-ainesadon kehittyminen kasvukauden aikana.

Figure 1. Development of the dry matter yield of Pito potato during the growing period.

T y p pila n n o it us lisäsi kasvukauden kuluessa enenevässä määrässä koko kasvuston kuiva-ainesatoa (N, BN, Piirros 2), tosin vuosittain vaihdellen (AN, ABN). $\mathrm{N}_{2}$-lannoitus ei kuitenkaan lisännyt enää kuiva-ainesatoa $\mathrm{N}_{1}$ :een verrattuna. Mukuloiden ja varsien kuiva-ainesadon suhde muuttui N-lannoitusta lisättäessä varsien kuiva-ainesadon kasvaessa nopeammin kuin mukuloiden. Tämän totesi myös CARPENTER (1957). Samoin kuiva-aineen kerääntyminen mukuloihin hidastui kasvukauden alussa sekä $\mathrm{N}_{1^{-}}$että $\mathrm{N}_{2}$-lannoitusta käytettäessä ja myös kasvukauden lopulla $\mathrm{N}_{2}$-lannoitusta käytettäessä (CN, $\mathrm{BCN}$ ). Vuotuista vaihtelua esiintyi myös tässä varsien ja mukuloiden kuivaainesatojen suhteessa (ACN). 


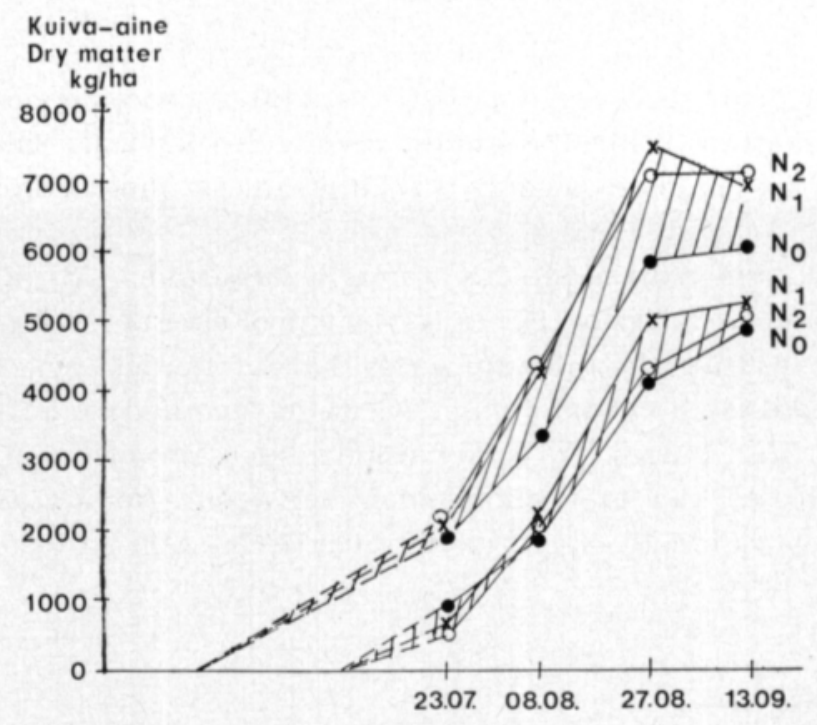

Piirros 2. N-lannoituksen vaikutus Pito-perunan kuiva-ainesadon kehittymiseen.

Figure 2. Effect of $N$ application on the development of the dry matter yield of Pito potato.

Fosforilannoit uksen kuiva-ainesatoa lisäävä vaikutus oli johdonmukaista. Ainoastaan lievä yhdysvaikutus BCP osoitti, että kasvukauden alkupuolella fosforilannoitus hidasti kuiva-aineen kerääntymistä mukuloihin, kun taas kasvukauden loppupuolella sekä kokonaiskuiva-ainesato että mukuloiden kuiva-ainesato lisääntyivät tasaisesti fosforilannoituksen määrien mukaisesti (Piirros 3).

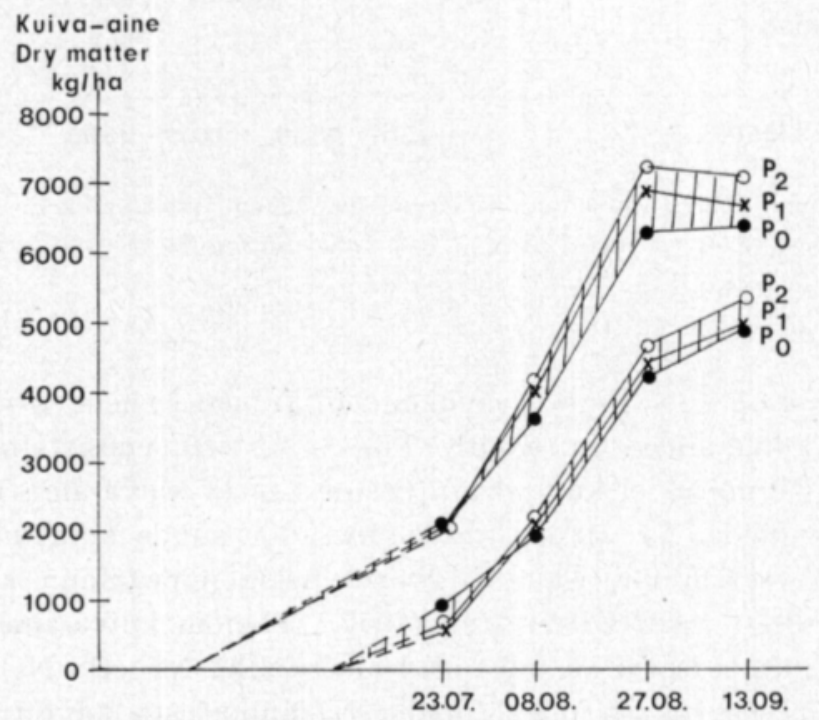

Piirros 3. P-lannoituksen vaikutus Pito-perunan kuiva-ainesadon kehittymiseen.

Figure 3. Effect of $P$ application on the development of the dry matter yield of Pito potato. 
K a li l a n n o it u s ei vaikuttanut merkitsevästi keskimääräiseen kuivaainesatoon, joskin suunta oli laskeva. Lievä yhdysvaikutus BCK osoitti, että kasvukauden lopulla $\mathrm{K}_{1}$-lannoitusta käytettäessä varsien ja mukuloiden kuivaainesatojen suhde poikkesi $\mathrm{K}_{2}$-lannoituksesta varsien kuiva-ainesadon jyrkän laskun takia edellisessä tapauksessa (vrt. Piirros 2). Kalilannoituskin hidasti kasvukauden alussa mukuloiden kuiva-ainesadon muodostumista, mutta muista poiketen myös kokonaiskuiva-ainesato jäi pienemmäksi, koska varsienkaan kuiva-ainesato ei lisääntynyt.

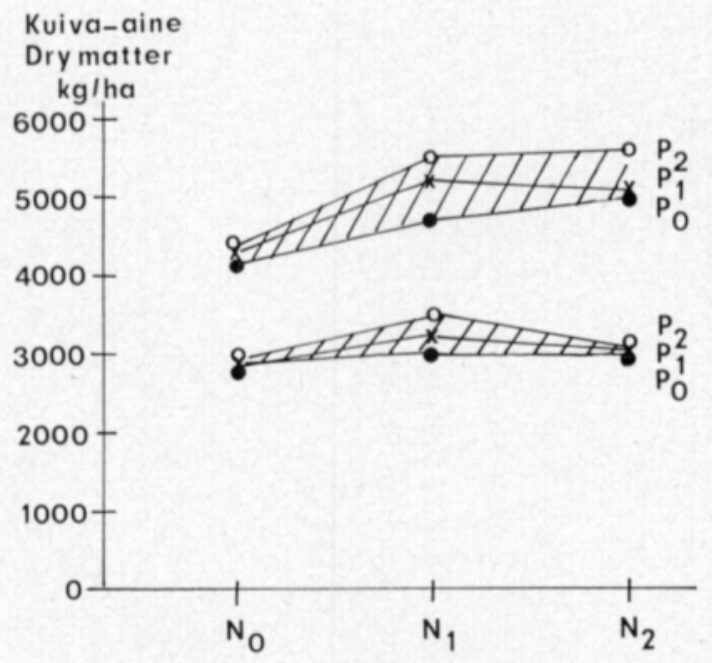

Piirros 4. NP-yhdysvaikutus Pito-perunan kuiva-ainesatoon.

Figure 4. NP interaction effect on the dry matter yield of Pito potato.

Typellä ja fosforilla oli yhdysvaikutus (NP, Taulukko 1 ja Piirros 4).

Piirroksen ylemmistä käyristä näkyy, miten runsas fosforilannoitus paransi typpilannoituksen vaikutusta $\left(\mathrm{N}_{2} \mathrm{P}_{2}\right) \cdot \mathrm{N}_{1}$-tasolla taas kohtuullinen fosforimäärä $\left(\mathrm{P}_{1}\right)$ antoi jo hyvän tuloksen. Yhdysvaikutuksessa oli vuotuista vaihtelua (ANP). Alemmista käyristä näkyy yhdysvaikutus CNP, minkä mukaan pelkkä typpilannoitus $\left(\mathrm{P}_{0}\right)$ tai runsas $\mathrm{N}$-lannoitus fosforin yhteydessäkin $\left(\mathrm{N}_{2}\right)$ lisäsivät ainoastaan varsien kuiva-ainesatoa. Mukuloiden kuiva-ainesadon kannalta $\mathrm{N}_{1} \mathrm{P}_{2}$-lannoitus oli selvästi edullisin. Tällöin koko perunan kuivaainesato nousi kolmannessa nostossa $8016 \mathrm{~kg}$ :aan ja mukuloiden kuiva-ainesato syksyllä $5793 \mathrm{~kg}$ :aan/ha (Piirros 1). Tämä yhdysvaikutus oli tullut esille myös samanlaisessa laajemmassa tutkimuksessa tärkkelyssadon suhțeen (VARIS 1973 a).

Kaliumilla ja fosforilla oli myös lieviä yhdysvaikutuksia (BPK ja CPK). Edellinen osoitti, miten pelkkä yksipuolinen kalilannoitus vähensi perunan kuiva-aineenmuodostusta sekä kasvukauden alkupuolella että lopulla. Yhdysvaikutus $\mathrm{CPK}$ puolestaan osoitti, miten tämä yksipuolisen kalilannoituksen kuiva-ainesatoa alențava vaikutus kohdistui vain varsistoon, mutta ei mukuloihin. $\mathrm{P}_{1}$-tasolla edullisin kalilannoitus oli $\mathrm{K}_{1}, \mathrm{P}_{2}$-tasolla $\mathrm{K}_{2}$. Kaliumin 
ja fosforin oikealla suhteella näytti siis myös olevan merkitystä perunan kuivaaineen tuotannossa (vrt. VARIS 1973 a).

\section{Typpi}

Pito-perunan maasta ottama typpimäärä vaihteli vuosittain (A) ja lisääntyi kasvukauden kuluessa (B). Varsien ja lehtien typpimäärissä oli samoin selvä ero (C). Yhdysvaikutukset $\mathrm{AB}, \mathrm{AC}, \mathrm{BC}$ ja $\mathrm{ABC}$ olivat myös merkitsevät (Piirros 5). Kaikki nämä typpimäärien vaihtelut johtuivat sekä kuiva-aineen määrän että sen $\mathrm{N}$-pitoisuuden muutoksista (Taulukko 1).

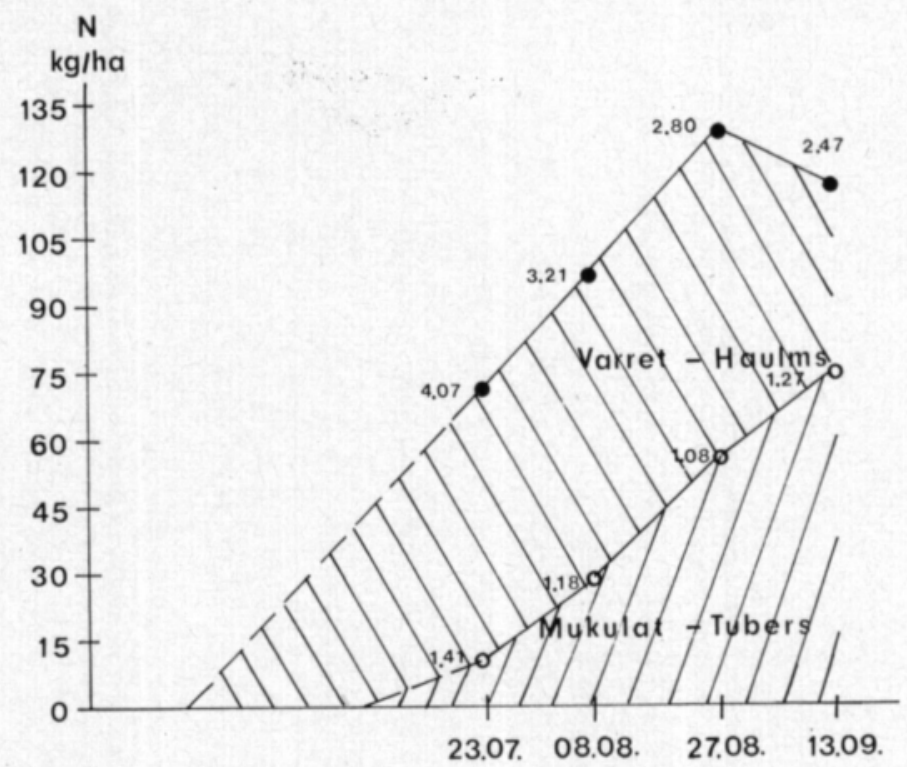

Piirros 5. Pito-perunan typen käyttö kasvukauden aikana.

Figure 5. $N$ uptake of Pito potato during the growing period.

Perunan käyttämä kokonaistyppimäärä oli mukulasadon kannalta edullisimmassa tapauksessa $\left(\mathrm{N}_{1} \mathrm{P}_{2}\right) 129 \mathrm{~kg} / \mathrm{ha}$. Mukuloissa oli tällöin syksyllä 75 $\mathrm{kg} / \mathrm{ha}$ typpeä. CARPENTERin (1957) tutkimusten mukaan perunan kokonaistyppimäärä nousi n. $100 \mathrm{~kg} / \mathrm{ha}$, josta määrästä n. puolet oli mukuloissa. KUNKELin ym. (1973) tutkimuksissa Russet Burbank-perunan sisältämä kokonais $\mathrm{N}$-määrä oli syksyllä n. $160 \mathrm{~kg} / \mathrm{ha}$ ja mukulasadossa poistui $\mathrm{n} .30 \mathrm{~kg}$ 10 tonnia kohti.

Typpilannoitus vaikutti oletetusti perunan käyttämään typpimäärään, vuosittain tosin vaihtelevalla tavalla (N, AN, Piirros 6). Typpilannoitus lisäsi kasvukauden kuluessa eniten varsiston typpimäärää, mutta kasvukauden loppupuolella myös mukulasadon typpimäärä kasvoi typpilannoituksen mukaan. Varsien $\mathrm{N}$-pitoisuus nousi varsinkin alkukesästä typpilannoitusta lisättäessä, kuten myös CARPENTER (1963) totesi. Varsien N-pitoisuus 


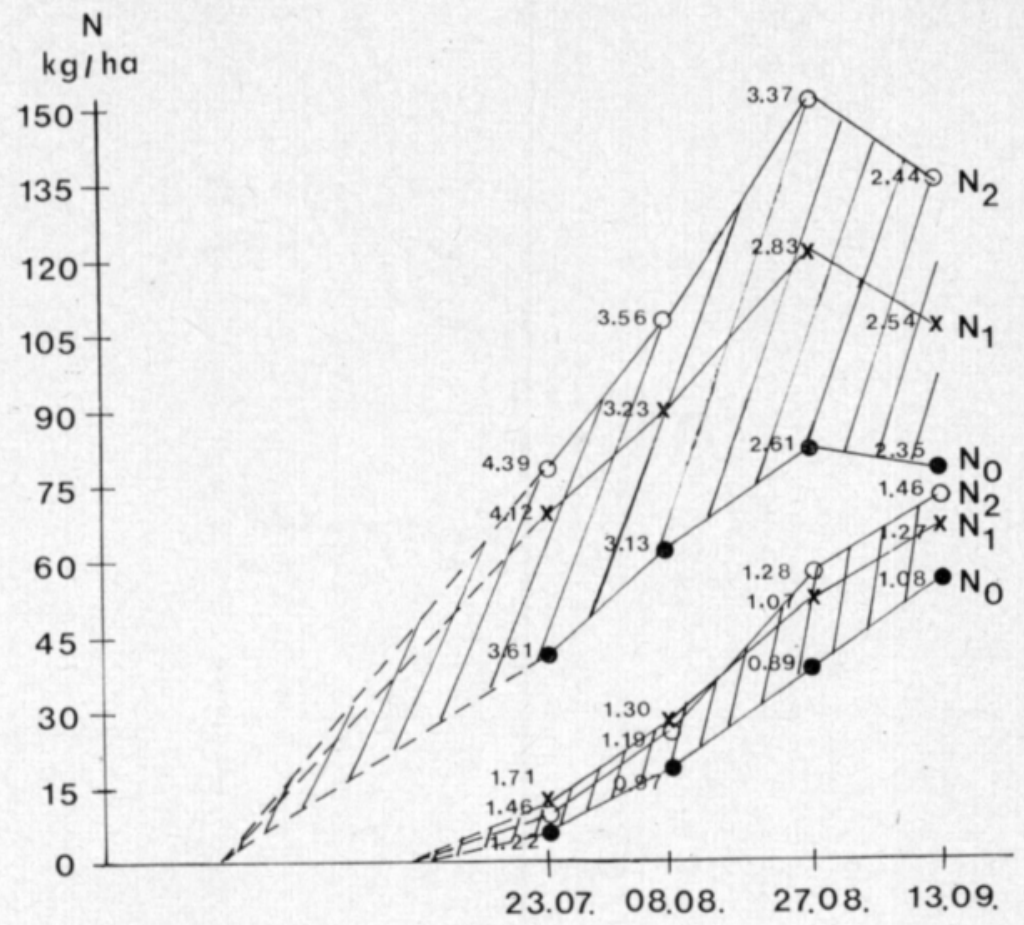

Piirros 6. N-lannoituksen vaikutus Pito-perunan typen käyttöön kasvukauden aikana. Figure 6. Effect of $N$ application on $N$ uptake of Pito potato during the growing period.

aleni syksyä kohti, mutta mukuloiden $\mathrm{N}$-pitoisuus nousi syksyllä, mikä osoittaa typen siirtymistä varsistosta mukuloihin. Typpeä siirtyi mukuloihin sitä enemmän mitä runsaampaa typpilannoitusta käytettiin (yhdysvaikutukset $\mathrm{BN}, \mathrm{ABN}, \mathrm{CN}, \mathrm{ACN}$ ja BCN). CARPENTERin (1957) mukaan typen siirtyminen varsistosta mukuloihin alkoi 95 pv:n kasvuajan jälkeen.

Merkille pantavaa on, että $\mathrm{N}_{0}$-tasolla peruna käytti jo keskimäärin 83 $\mathrm{kg} /$ ha typpeä, $\mathrm{N}_{1}$-tasolla $(100 \mathrm{~kg} \mathrm{~N}) 129 \mathrm{~kg}$, ja $\mathrm{N}_{2}$-tasolla $(200 \mathrm{~kg} \mathrm{~N}) 155 \mathrm{~kg}$ typpeä. Mukulasadossa maasta poistui $51-75 \mathrm{~kg}$ typpeä, joten maan typpivarasto lisääntyi typellä lannoitettaessa huomattavasti varsien jäädessä maahan ja osan typestä jäädessä kokonaan käyttämättä.

F o s f o r i l a n n o i t u s lisäsi myös perunan typen käyttöä, tosin vuosittain vaihtelevassa määrässä ( $\mathrm{P}, \mathrm{AP}, \mathrm{ABP}, \mathrm{ACP})$. Tämä johtui kuitenkin pääasiassa fosforilannoituksen aiheuttamasta kuiva-ainesadon lisääntymisestä. Yhdysvaikutus BCP osoitti, että fosforilannoitus vaikutti myös typen määrien suhteeseen varsissa ja mukuloissa kasvukauden aikana. Nämäkin muutokset johtuivat ainoastaan kuiva-aineen määrän muutoksista (vrt. Piirros 3). Varsien kuiva-aineen $\mathrm{N}$-pitoisuus näytti tosin alenevan kasvukauden loppupuolella P-lannoitusta lisättäessä, mikä ero ei kuitenkaan ollut tilastollisesti merkitsevä. Samanaikaisesti mukuloiden kuiva-aineen määrä lisääntyi selvästi typpipitoisuuden silti alenematta. Nämä ilmiöt viittaavat runsaan fosforilannoituksen kykyyn nopeuttaa typen siirtymistä varsista mukuloihin. 


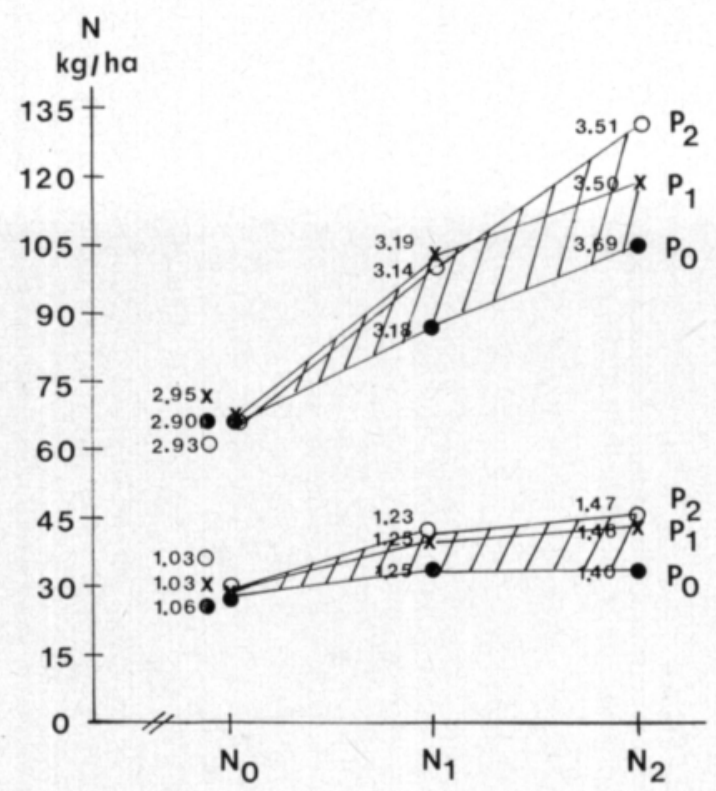

Piirros 7. NP-yhdysvaikutus Pito-perunan typen käyttöön.

Figure 7. NP interaction effect on $N$ uptake of Pito potato.

Typellä ja fosforilla oli myös yhdysvaikutus, tosin vuosittain vaihteleva (NP, ANP, Piirros 7). Sen mukaan typen ja fosforin sopiva suhde $\left(\mathrm{N}_{1} \mathrm{P}_{1}\right.$ tai $\mathrm{N}_{2} \mathrm{P}_{2}$ ) aiheutti perunalla suurimman typen käytön. Lisäksi yhdysvaikutus CNP osoitti, että kuiva-aineen $\mathrm{N}$-pitoisuus laski varsissa ja nousi mukuloissa fosforilannoitusta lisättäessä $\mathrm{N}_{2}$-tasolla. Tämä tulos oli myös osoituksena typen nopeammasta varastoitumisesta mukuloihin runsasta fosforilannoitusta käytettäessä. Ruotsalaisissa tutkimuksissa todettiin fosforilannoituksen alentavan jossain määrin mukuloiden N-pitoisuutta (HAHLin ja JoHAnsson 1973).

K a lil a n n o it us ei vaikuttanut perunan typen käyttöön. Ainoastaan jonakin vuonna typellä ja kaliumilla sekä fosforilla ja kaliumilla oli yhdysvaikutuksia (ANK, APK). Myös kaikilla ravinteilla oli yhdysvaikutus (NPK). Runsaiden typpi- ja fosforimäärien ollessa kyseessä $\left(\mathrm{N}_{1}, \mathrm{~N}_{2}, \mathrm{P}_{1}, \mathrm{P}_{2}\right)$ kaliumin määrällä oli vaihteleva, vaikeasti tulkittava vaikutus perunan typen käyttöön. [Hahlin ja Johansson (1973) totesivat samoin kalilannoituksen epäsäännöllisen vaikutuksen perunoiden $\mathrm{N}$-pitoisuuteen.

\section{Fosfori}

Perunan käyttämä fosforimäärä vaihteli vuosittain (A) ja lisääntyi kasvukauden kuluessa (B). Kokonaisfosforimäärä oli $\mathrm{N}_{1} \mathrm{P}_{2}$-lannoitusta käytettäessä suurimmillaan n. $15 \mathrm{~kg} / \mathrm{ha}$. Mukulasadon fosforimäärä nousi säännöllisesti ollen syksyllä suhteellisen suuri, n. $11 \mathrm{~kg} / \mathrm{ha}(\mathrm{C})$. Varsien fosforimäärä sen sijaan pysyi suhteellisen muuttumattomana koko kasvukauden ajan (BC, Piirros 8). 


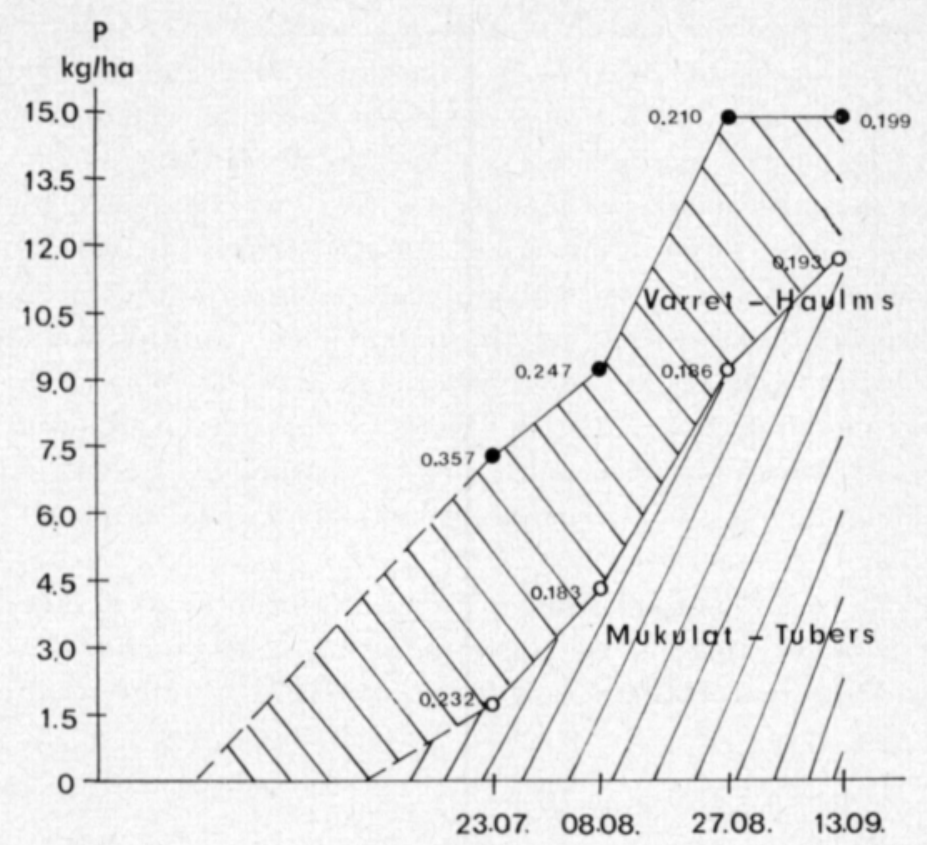

Piirros 8. Pito-perunan fosforin käyttö kasvukauden aikana.

Figure 8. $P$ uptake of Pito potato during the growing period.

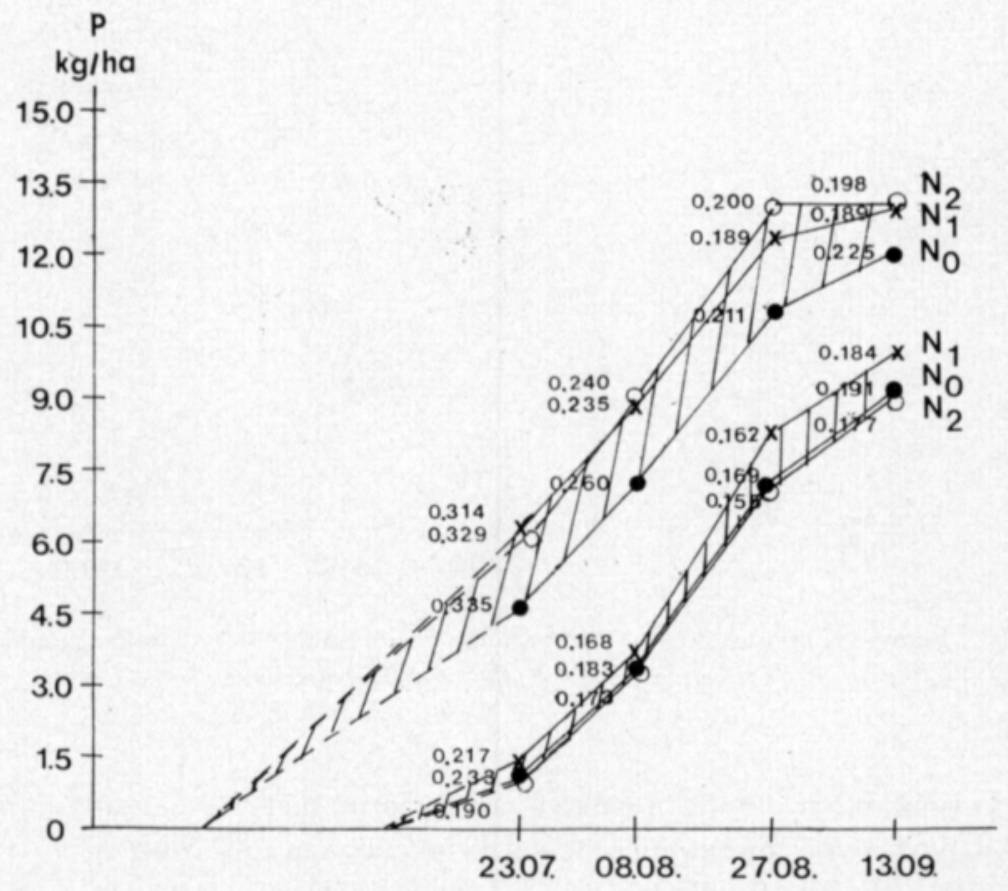

Piirros 9. N-lannoituksen vaikutus Pito-perunan fosforin käyttöōn kasvukauden aikana. Figure 9. Effect of $N$ application on $P$ uptake of Pito potato during the growing period. 
Kaikki nämä muutokset johtuivat sekä kuiva-aineen määrän että sen fosforipitoisuuden vaihțeluista. Vuotuiset vaihtelut olivat huomattavat (AB, AC, ABC). CARPENTERin (1957) tutkimuksissa perunan kokonaisfosforimäärä nousi n. $12 \mathrm{~kg}$ :aan/ha, mukuloiden $7.4 \mathrm{~kg}$ :aan/ha. Kunkelin ym. (1973) tutkimuksessa mukulasadossa poistui fosforia (P) $7 \mathrm{~kg} 10$ tonnia kohti.

Typpilannoitus lisäsi koko kasvin, erityisesti varsiston fosforinottoa pääasiassa lisääntyneen kuiva-aineen tuotannon myötä $(\mathrm{N}, \mathrm{AN}, \mathrm{CN}$, $\mathrm{ACN})$. Kuitenkin sekä varsiston että mukuloiden fosforipitoisuudet alenivat typpilannoitusta lisättäessä, joten fosforimäärät eivät nousseet yhtä paljon kuin kuiva-ainesadot (BN, $\mathrm{ABN}$, Piirros 9). Runsas typpilannoitus $\left(\mathrm{N}_{2}\right)$ näytti sitäpaitsi hidastavan fosforin siirtymistä mukuloihin kasvukauden lopulla (BCN), mikä ilmiö näkyy varsiston ja mukuloiden kuiva-aineen fosforipitoisuuksien kehityksessä.

Fosforila n n o it us lisäsi perunan fosforin käyttöä kuiva-ainesatoa lisäämällä ja myös kuiva-aineen fosforipitoisuutta nostamalla ( $\mathrm{P}, \mathrm{AP}$, Piirros 10). Saman totesivat Hahlin ja Johansson (1973). Suuri fosforimäärä $\left(P_{2}\right)$

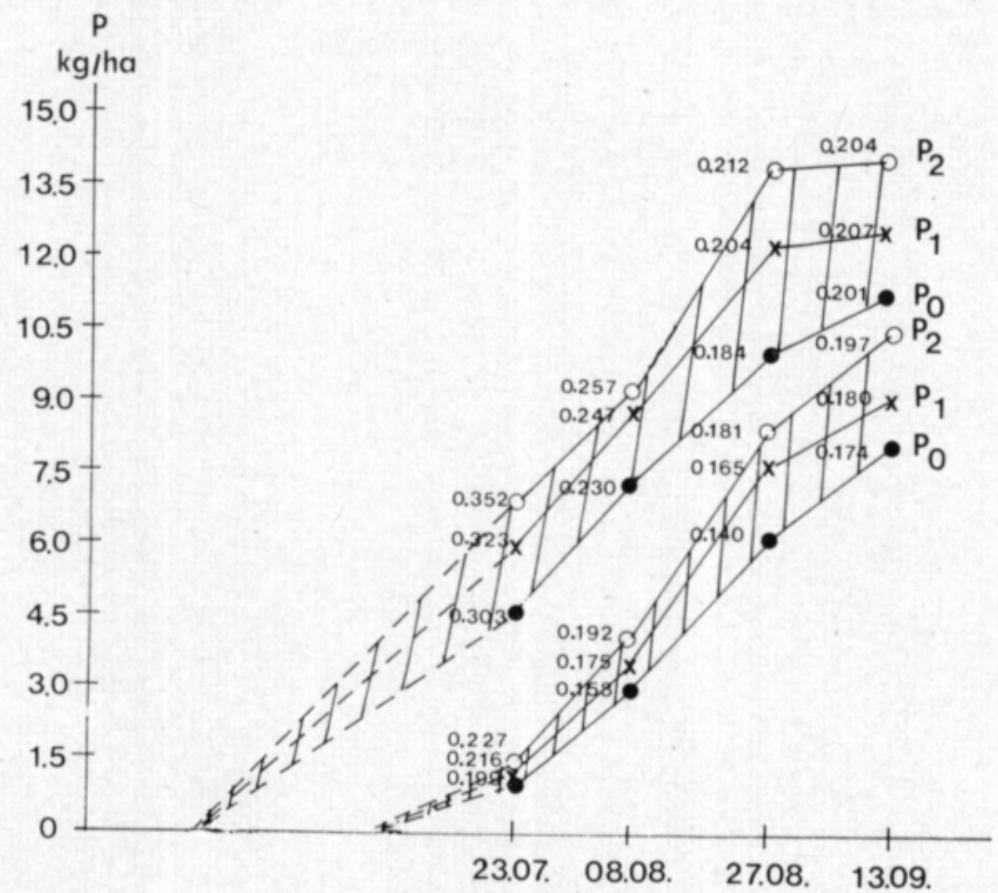

Piirros 10. P-lannoituksen vaikutus Pito-perunan fosforin käyttöön kauden aikana.

Figure 10. Effect of $P$ application on $P$ uptake of Pito potato during the growing period.

näytti kasvukauden lopulla nopeuttavan fosforin siirtymistä mukuloihin, mikä näkyy varsiston ja mukuloiden fosforipitoisuuksien muutoksista kasvukauden lopulla (BP, CP, BCP). Vuotuista vaihtelua esiintyi (ABP).

$\mathrm{K}$ a lila n noit u ksen vaikutus perunan fosforin käyttöön oli merkityksetön (ACK). Hahlin ja Johansson (1973) totesivat kalilannoituksen 
lievästi alentavan mukuloiden fosforipitoisuutta, mutta kalilannoituksen vaikutus perunan fosforikäyttöön kokonaisuudessaan oli merkityksetön.

Typellä ja fosforilla oli myös fosforin käyttöön nähden yhdysvaikutus (NP, ANP), mikä ei rajoittunut yksinomaan kuiva-aineen määrän muutok-

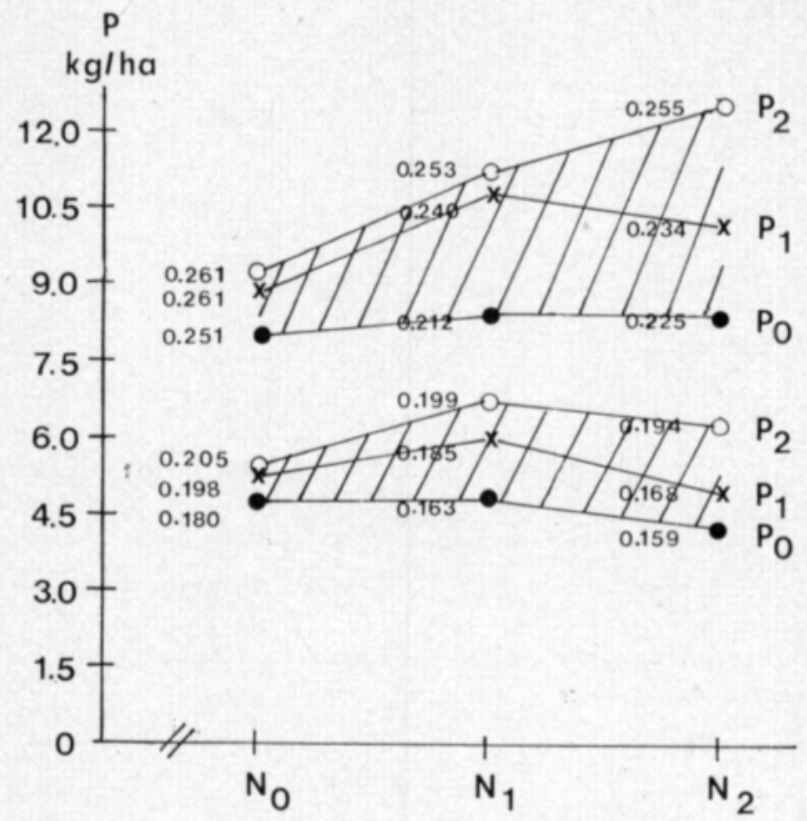

Piirros 11. NP-yhdysvaikutus Pito-perunan fosforin käyttöön.

Figure 11. NP interaction effect on P uptake of Pito potato.

siin (Piirros 11). Typpilannoitusta lisättäessä koko kasvin ottama fosforimäärä lisääntyi sekä kuiva-aineen määrän lisääntyessä että sen fosforipitoisuuden noustessa $\mathrm{N}_{1}$-tasoon saakka. $\mathrm{N}_{2}$-tasolla sen sijaan fosforimäärä lisääntyi ainoastaan $\mathrm{P}_{2}$-lannoituksella. Mukuloiden fosforimääriin ja -pitoisuuksiin runsas typpilannoitus $\left(\mathrm{N}_{2}\right)$ vaikutti vielä enemmän jarruttavasti kuin koko kasviin (CNP).

Typellä ja kaliumilla oli jonakin vuonna yhdysvaikutus (ANK), samoin kaikilla ravinteilla (NPK). Näistä kävi selville, että runsasta N- tai NP-lannoitusta $\left(\mathrm{N}_{2}, \mathrm{~N}_{2} \mathrm{P}_{2}\right)$ käytettäessä perunan ottama fosforimäärä aleni erityisesti, jos kalilannoitusta lisättiin samanaikaisesti.

Perunan käyttämä fosforimäärä oli vain murto-osa lannoituksena annetusta. $\mathrm{P}_{0}$-tasolla se nousi $11 \mathrm{~kg}$ :aan ja $\mathrm{P}_{2}$-tasolla $(174 \mathrm{~kg} / \mathrm{ha} \mathrm{P}) 15 \mathrm{~kg}$ :aan. Mukulasadon osuus koko fosforimäärästä oli vastaavasti $8-11 \mathrm{~kg} / \mathrm{ha}$.

\section{Kalium}

Perunan käyttämä kaliummäärä vaihteli myös vuosittain (A) ja suureni kasvukauden aikana (B). Kokonaiskaliummäärä oli kolmannessa nostossa $\mathrm{N}_{1} \mathrm{P}_{2}$-lannoituksella $230 \mathrm{~kg} / \mathrm{ha}$. Mukuløissa oli tällöin syksyllä kaliumia 122 


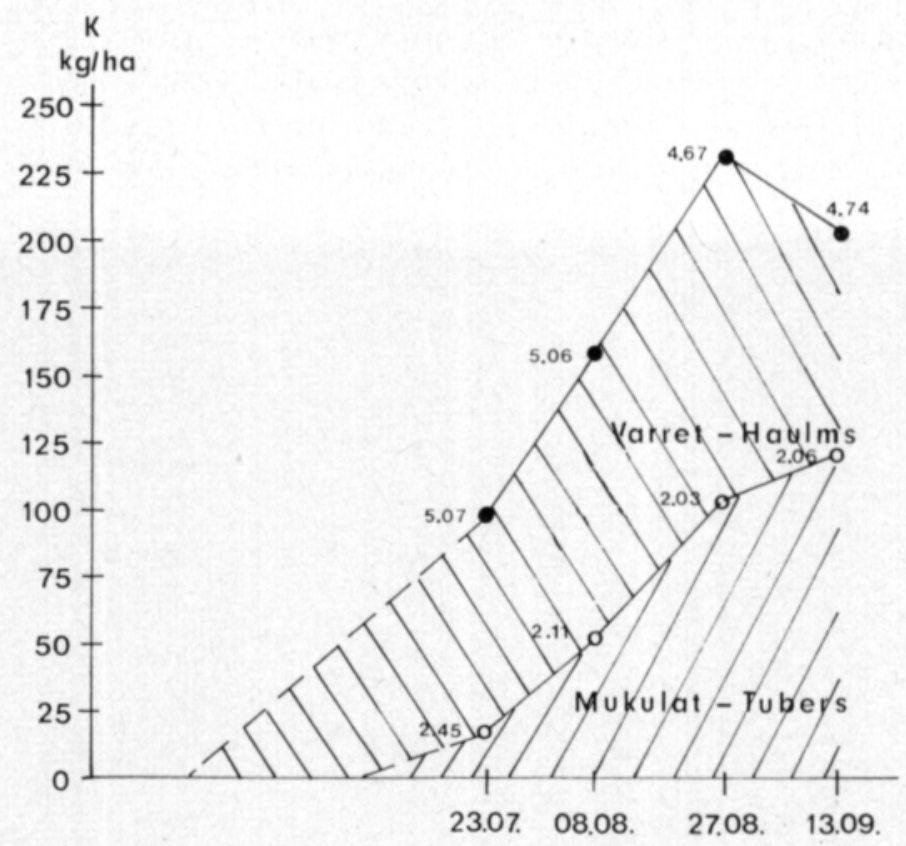

Piirros 12. Pito-perunan kaliumin käyttö kasvukauden aikana.

Figure 12. K uptake of Pito potato during the growing period.

$\mathrm{kg} / \mathrm{ha}$. Lehtien ja varsien kaliummäärä oli erilainen (C) ja muuttui kasvukauden kuluessa (BC, Piirros 12). Kaikki nämä muutokset johtuivat sekä kuivaaineen määrän että sen kaliumpitoisuuden muutoksista. Kaikissa eroissa oli vuotuista vaihtelua (AB, AC, ABC). CARPEnterin (1957) tutkimuksissa oli vastaavasti kaliumin kokonaismäärä n. $190 \mathrm{~kg} / \mathrm{ha}$, josta mukuloissa $\mathrm{n} .85 \mathrm{~kg}$. KUNKELin ym. (1973) tutkimuksissa kaliumia oli mukulasadossa $44 \mathrm{~kg} /$ $10 \mathrm{tn}$.

Typpilannoitus lisäsi perunan kaliumin käyttöä (N, AN, BN, ABN). Tämä johtui suurimmaksi osaksi kuiva-ainesadon lisääntymisestä, mutta jossain määrin myös samanaikaisesta kuiva-aineen kaliumpitoisuuden noususta (Piirros 13).

Typpilannoitus lisäsi pääasiassa varsiston kaliummäärää ja myös sen kaliumpitoisuutta. Sen sijaan mukuloiden kaliumpitoisuus pysytteli sangen tasaisena typpilannoituksesta riippumatta ( $\mathrm{CN}, \mathrm{ACN}, \mathrm{BCN})$.

Fosforila n noit us lisäsi perunan kaliuminottoa (,$A B P)$, mutta enemmän varsiston kuin mukuloiden ( $\mathrm{CP}$, Piirros 14). Fosforilannoituksella näytti toisaalta olevan taipumusta jarruttaa perunan kaliumin ottoa, sillä runsas fosforimäärä $\left(\mathrm{P}_{2}\right)$ alensi kasvukauden lopulla varsiston kuiva-aineen kaliumpitoisuutta. Samoin molemmat käytetyistä fosforiannoksista $\left(\mathrm{P}_{1}\right.$ ja $\left.\mathrm{P}_{2}\right)$ pitivät mukuloiden kaliumpitoisuudet kasvukauden lopulla alhaisina. Samoin HaHLin ja JoHANsson (1973) totesivat fosforilannoituksen pystyvän vähentämään perunan kaliumin ottoa.

K a li l a n n o it us ei näissä koeoloissa lisännyt merkitsevästi perunan käyttämää kaliummäärää, vaikkakin kuiva-aineen kaliumpitoisuus nousi 


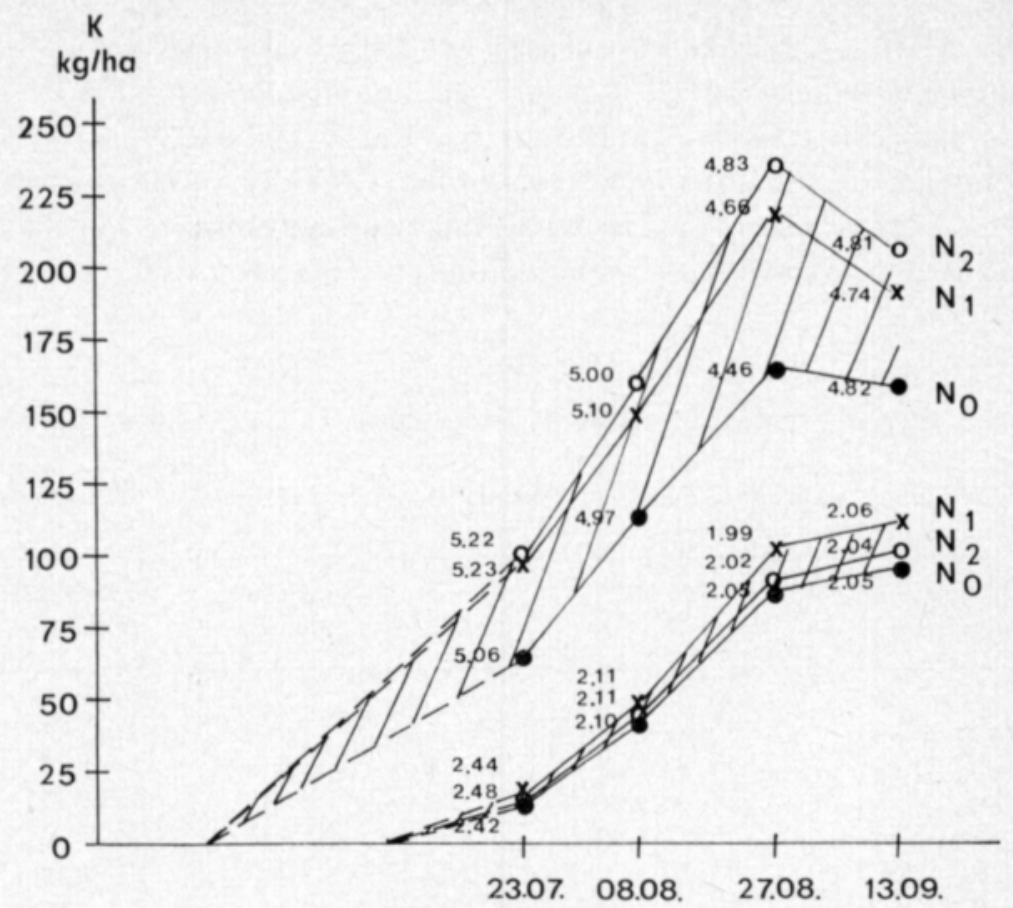

Piirros 13. N-lannoituksen vaikutus Pito-perunan kaliumin käyttōön kasvukauden aikana. Figure 13. Effect of $N$ application on $K$ uptake of Pito potato during the growing period.

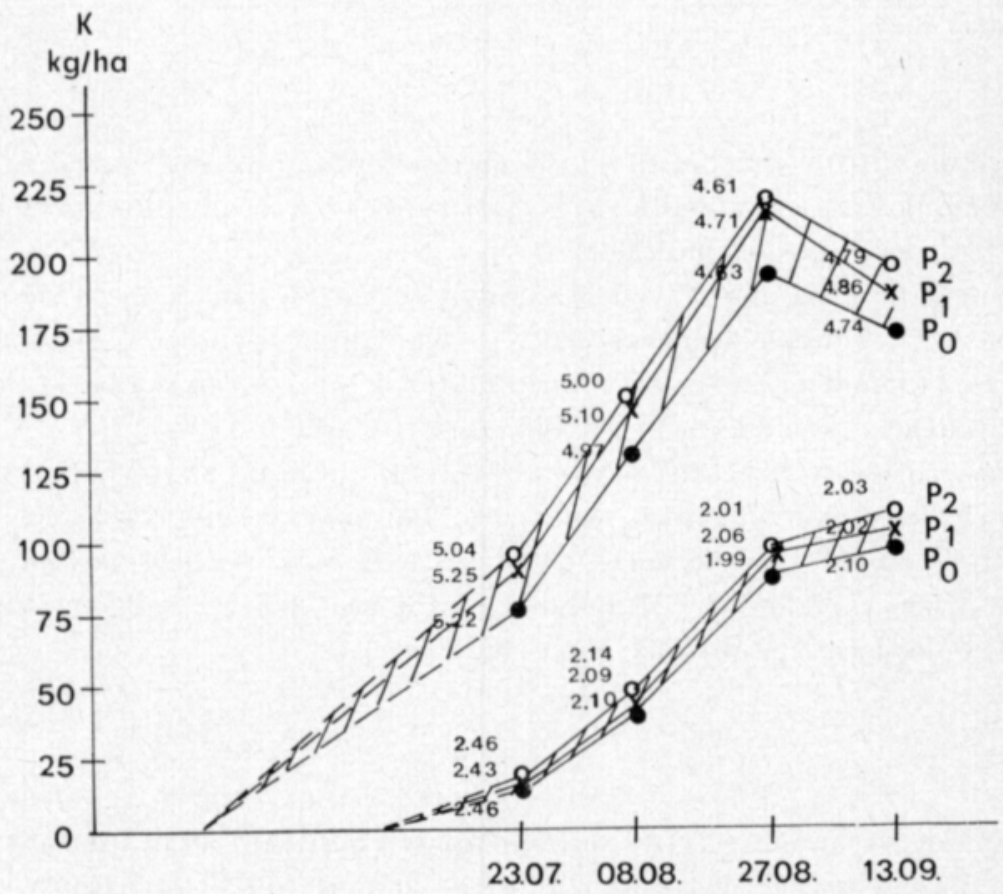

Piirros 14. P-lannoituksen vaikutus Pito-perunan kaliumin käyttöön kasvukauden aikana. Figure 14. Effect of $P$ application on $K$ uptake of Pito potato during the growing period. 
(K, AK, ABK). Nousu kohdistui sekä lehdistöön että mukuloihin, tosin voimakkaampana edelliseen (K, ACK). Kaliumpitoisuuden nousun totesivat myös Carpenter (1963) sekä Hahlin ja Johansson (1973).

Ravinteilla oli muutamia yhdysvaikutuksia. Yhdysvaikutukset NP, ANP ja CNP noudattivat kuiva-ainesadoissa todettuja muutoksia. Typellä ja kaliumilla oli myös yhdysvaikutus kaliumpitoisuuksiin (NK, ANK ja CNK, Taulukko 2).

Taulukko 2. Typen ja kalin yhdysvaikutus Pito-perunan lehtien ja mukuloiden K-pitoisuuksiin.

Table 2. NK interaction effect on the $K$ content of haulms and tubers of Pito potato.

\begin{tabular}{|c|c|c|}
\hline $\begin{array}{l}\text { Lannoitus } \\
\text { Treatment }\end{array}$ & $\begin{array}{c}\text { Varsisto } \\
\text { Haulms }\end{array}$ & $\begin{array}{c}\text { Mukulat } \\
\text { Tubers }\end{array}$ \\
\hline 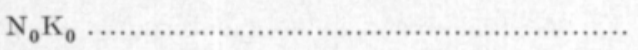 & 4.80 & 2.14 \\
\hline 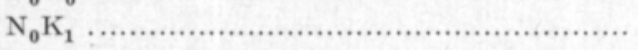 & 4.84 & 2.13 \\
\hline 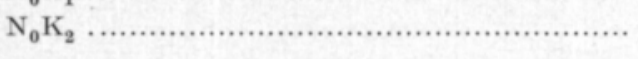 & 4.84 & 2.18 \\
\hline (n) & 4.78 & 2.10 \\
\hline 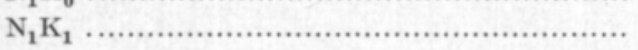 & 4.96 & 2.16 \\
\hline 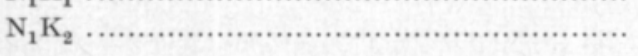 & 5.04 & 2.18 \\
\hline $\mathrm{N}_{2} \mathrm{~K}_{0}$ & 4.70 & 2.07 \\
\hline 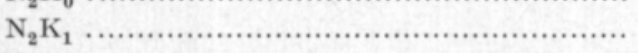 & 5.00 & 2.16 \\
\hline 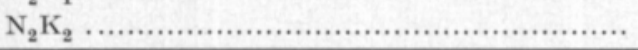 & 5.23 & 2.25 \\
\hline PME $-L S D(5 \%)$ & 0.22 & 0.08 \\
\hline
\end{tabular}

Kalilannoitusta lisättäessä kuiva-aineen kaliumpitoisuus nousi ainoastaan, jos samanaikaisesti käytettiin riittävästi typpeä. Ero oli suurempi lehdistössä, mutta tuli esille myös mukuloissa.

Fosforilannoitus muutti vielä kalilannoituksen kanssa perunan kaliumin käyttöä kasvukauden kuluessa (BPK). Kalilannoitus lisäsi perunan kaliumin ottoa kasvukauden alussa lukuunottamatta $\mathrm{P}_{2}$-tasoa. Syksyllä kalilannoituksen vaikutusta ei näkynyt millään fosforitasolla.

Lannoituksessa annetuista kaliummääristä peruna käytti vain osan. $\mathrm{K}_{0}$ tasolla Pito-peruna käytti keskimäärin kaliumia jo $199 \mathrm{~kg} / \mathrm{ha}$ ja $\mathrm{K}_{2}$-tasolla (332 kg/ha K) $214 \mathrm{~kg} / \mathrm{ha}$. $\mathrm{N}_{1} \mathrm{P}_{2}$-tasolla $\mathrm{K}$-määrä nousi, kuten edellä on esitetty, $230 \mathrm{~kg}$ :aan/ha. Mukuloissa kaliumia poistui maasta vastaavasti $103-104 \mathrm{~kg} / \mathrm{ha}, \mathrm{N}_{1} \mathrm{P}_{2}$-tasolla jopa $122 \mathrm{~kg}$.

Kalsium

Perunan kalsiumin käyttö vaihteli myös vuosittain (A) ja lisääntyi kasvukauden kuluessa (B). Kalsiumista, jonka määrä $\mathrm{N}_{1} \mathrm{P}_{2}$-lannoituksella oli suurimmillaan $42 \mathrm{~kg} / \mathrm{ha}$, oli syksyllä mukuloissa vain pieni osa, $2.2 \mathrm{~kg} / \mathrm{ha}$ (C). Varsiston kalsiumpitoisuus nousi kasvukauden alkupuolella, mutta aleni 


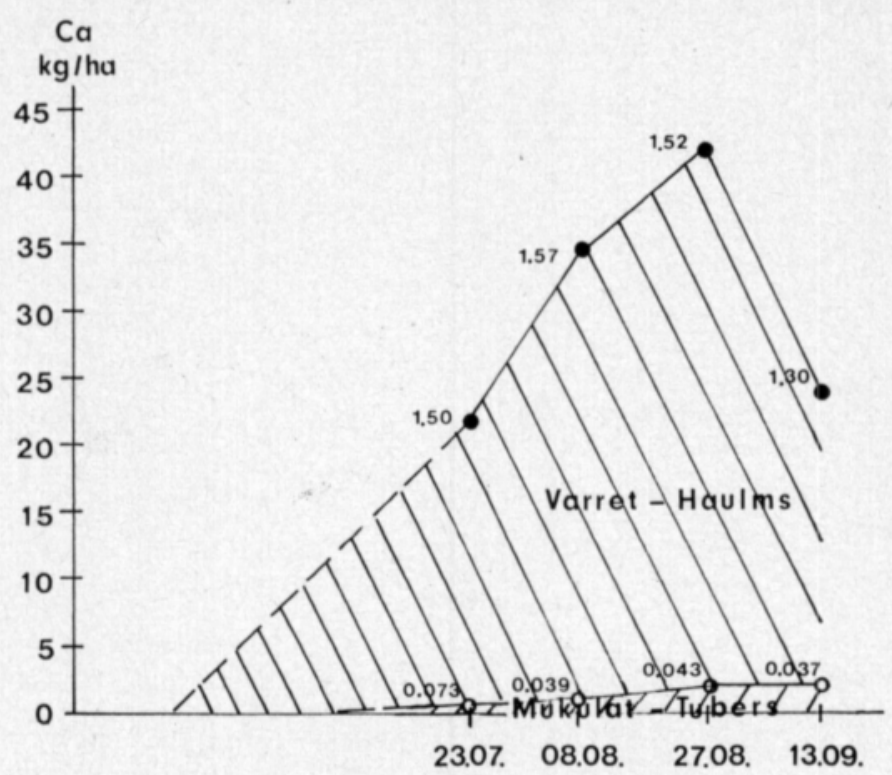

Piirros 15. Pito-perunan kalsiumin käyttō kasvukauden aikana.

Figure 15. Ca uptake of Pito potato during the growing period.

syksyllä. Mukuloiden Ca-pitoisuus pysyi alhaisena koko kasvukauden loppupuolen (BC, Piirros 15). Vuotuista vaihtelua esiintyi (AB, AC, ABC). CARPENTERin (1957) tutkimuksessa kalsiumin kokonaismäärä nousi 24 kg:aan/ha, mukuloiden kalsiummäärä peräti $6 \mathrm{~kg}$ :aan/ha. Kunkelin ym. (1973) tutkimuksissa kalsiumia (Ca) poistui maasta $0.8 \mathrm{~kg} / 10 \mathrm{tn}$.

Typpilannoitus vaikutti perunan kalsiumin käyttöön toisaalta lisäämällä kuiva-ainesadon määrää (N, AN, ABN), mutta toisaalta alentamalla kuiva-aineen kalsiumpitoisuutta ( $\mathrm{CN}, \mathrm{ACN}$, Piirros 16). Kalsiumin saanti siis vaikeutui typpilannoitusta lisättäessä. Vaikutus kohdistui pääasiassa varsistoon, sillä mukuloiden kalsiummäärät ja -pitoisuudet riippuivat varsin vähän typpilannoituksesta (BCN).

F o s f o r i la n n o i t u k e n kalsiumin käyttöä lisäävä vaikutus perustui pääasiassa kuiva-aineen määrän kasvamiseen ( $\mathrm{P}, \mathrm{AP}, \mathrm{BP}, \mathrm{ABP}$, Piirros 17). Fosforilannoituskin lisäsi pääasiassa varsiston kalsiummäärää $(\mathrm{CP}, \mathrm{ACP})$, mutta runsas fosforilannoitus edisti kuitenkin hiukan myös kalsiumin siirtymistä mukuloihin (BCP). HAHLIN ja Johnsson (1973) totesivat samoin fosforilannoituksen edistävän perunan kalsiumin käyttöä.

K a lilannoit us ei keskimäärin vaikuttanut merkitsevästi perunan kalsiumin käyttöön, joskin suunta oli vähenevä. Kuiva-aineen kalsiumpitoisuus aleni keskimäärin kalilannoitusta lisättäessä. Kohtuullinen kalimäärä $\left(\mathrm{K}_{1}\right)$ näytti jossain määrin muuttavan kalsiumsuhdetta mukuloiden eduksi (CK, ACK) pääasiassa vähentämällä varsiston kalsiummäärää. HAHLıvin ja JoHANssonin (1973) tutkimuksissa kalilannoitus nosti mukuloiden kuiva-aineen Ca-pitoisuutta, mutta ei vaikuttanut kalsiumin kokonaismääriin.

Ravinteilla oli muutamia yhdysvaikutuksia (NP, NK, ANP, BPK, CNP, 


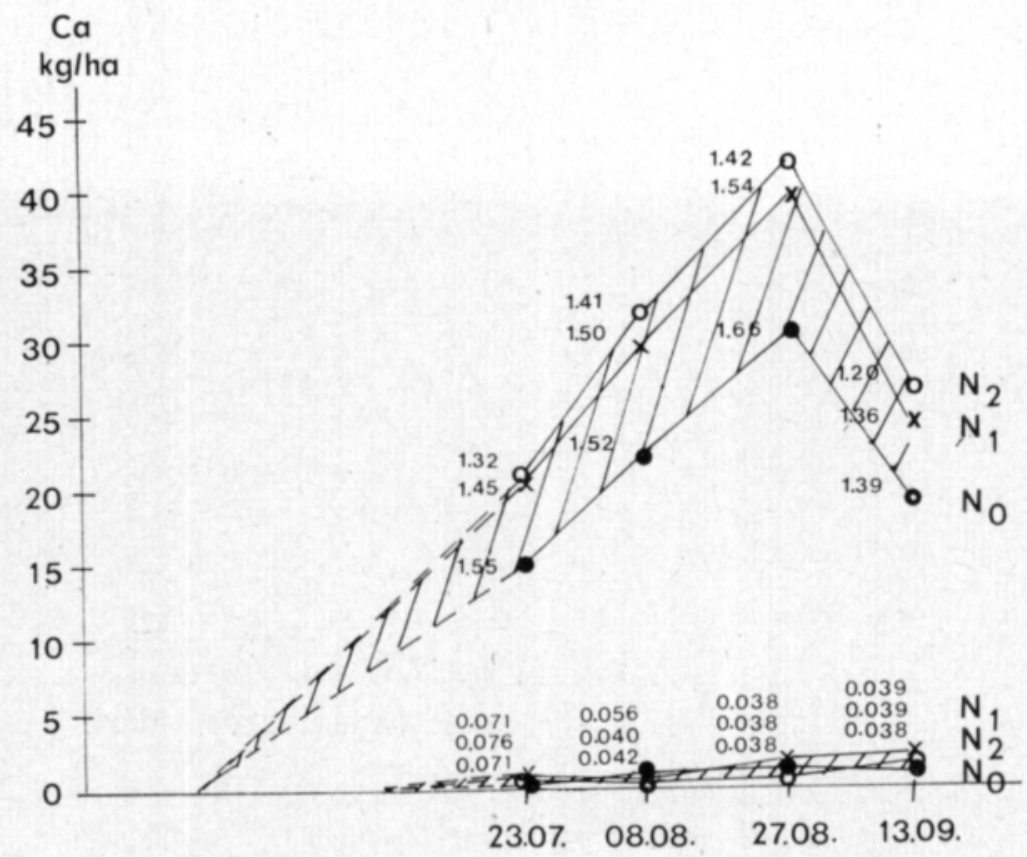

Piirros 16. N-lannoituksen vaikutus Pito-perunan kalsiumin käyttöôn kasvukauden aikana. Figure 16. Effect of $N$ application on Ca uptake of Pito potato during the growing period.

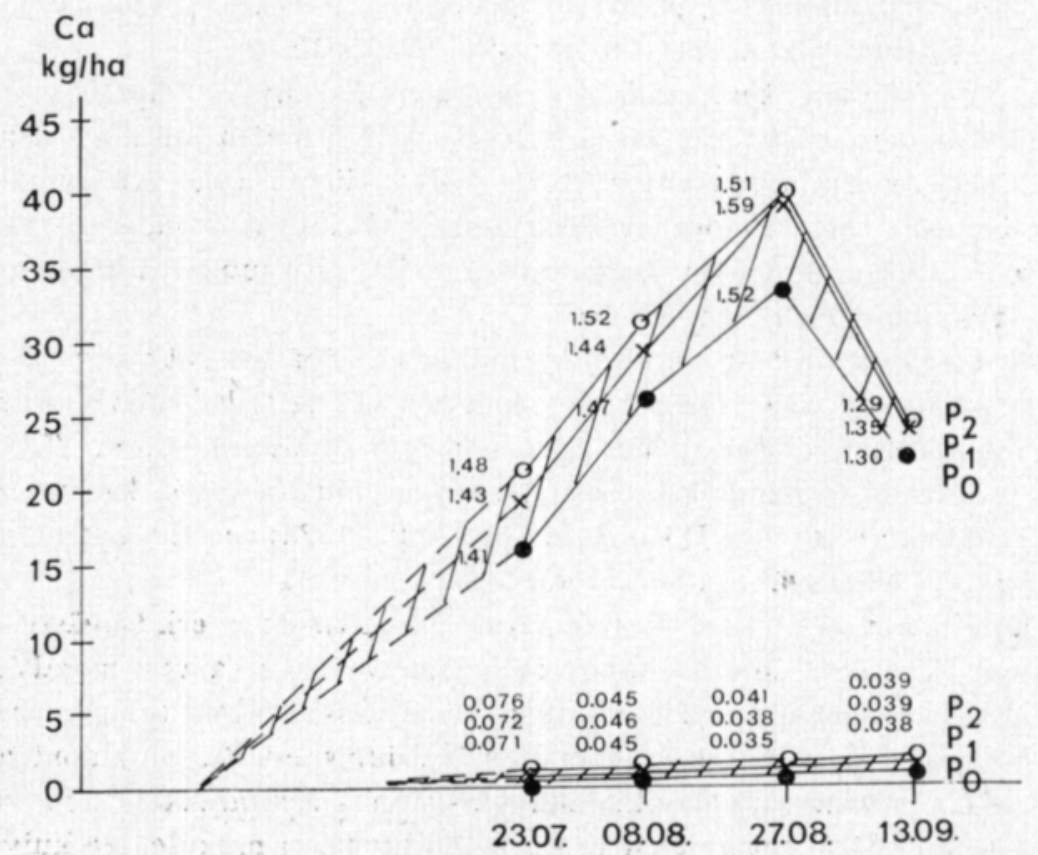

Piirros 17. P-lannoituksen vaikutus Pito-perunan kalsiumin käyttöön kasvukauden aikana. Figure 17. Effect of $P$ application on Ca uptake of Pito potato during the growing period. 
CNK), jotka kuitenkin suurimmaksi osaksi noudattivat kuiva-aineen muutoksia. Lievä yhdysvaikutus NPK osoitti kalsiummäärän nousevan suurimmaksi kun kalia käytettiin niukasti typpeen ja fosforiin verrattuna $\left(\mathrm{N}_{1} \mathrm{P}_{1} \mathrm{~K}_{0}, \mathrm{~N}_{2} \mathrm{P}_{2} \mathrm{~K}_{0}\right.$, $\mathrm{N}_{2} \mathrm{P}_{2} \mathrm{~K}_{1}$ ). Typpi ja kali vaikuttivat yhdessä varsiston kuiva-aineen kalsiumpitoisuuksiin siten, että ne lisäsivät toistensa kuiva-aineen kalsiumpitoisuutta alentavaa vaikutusta $\left(\mathrm{N}_{0} \mathrm{~K}_{0} 1.57, \mathrm{~N}_{2} \mathrm{~K}_{2}\right.$ 1.29). Mukuloissa ei tätä yhdysvaikutusta todettu.

\section{Magnesium}

Perunan magnesiumin käyttö vaihteli vuosittain (A) ja lisääntyi kasvukauden kuluessa (B). Magnesiumin kokonaismäärä nousi $\mathrm{N}_{1} \mathrm{P}_{2}$-lannoituksella kolmannessa nostossa $19 \mathrm{~kg}$ :aan/ha. Mukuloissa oli syksyllä tällöin magnesiumia $6 \mathrm{~kg} / \mathrm{ha}$. Pääosa magnesiumista oli siten lehdissä (C), joista sitä kasvukauden lopulla näytti siirtyvän mukuloihin (Piirros 18). Kaikissa näissä muu-

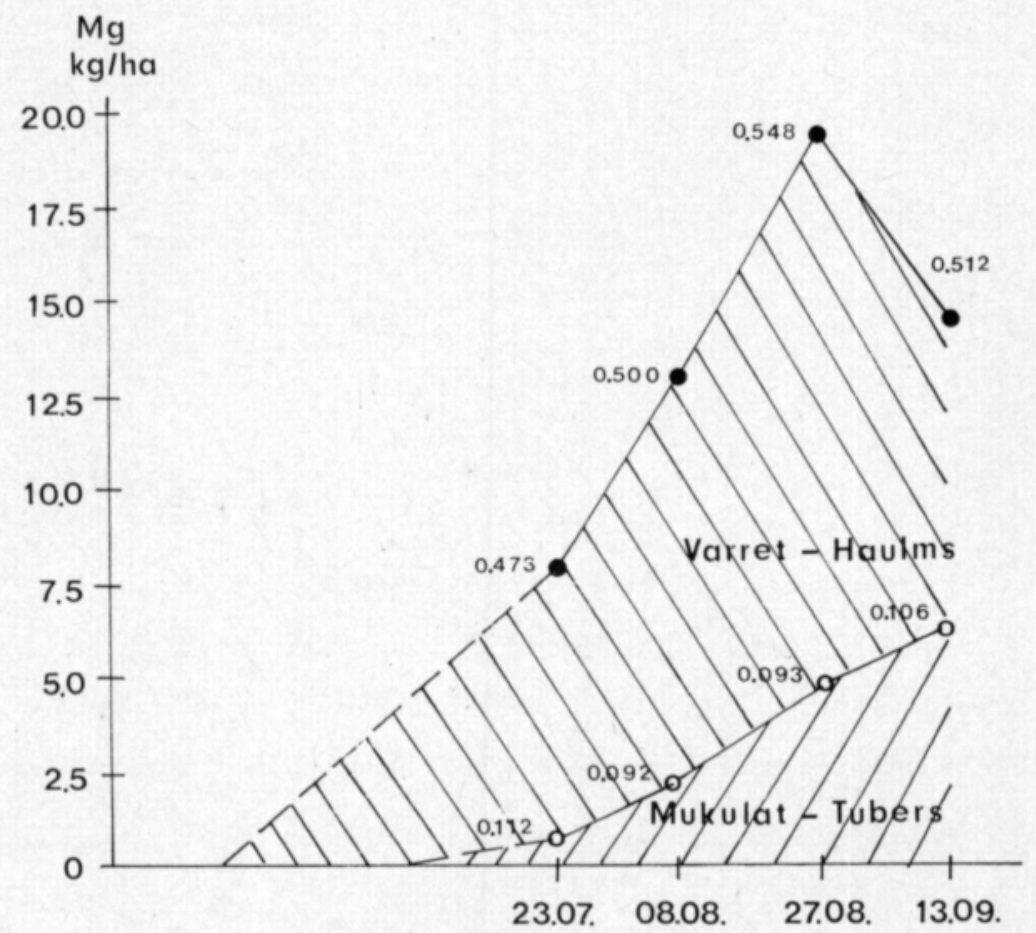

Piirros 18. Pito-perunan magnesiumin käyttö kasvukauden aikana.

Figure 18. Mg uptake of Pito potato during the growing period.

toksissa oli vuotuista vaihtelua $(\mathrm{AB}, \mathrm{AC}, \mathrm{BC}, \mathrm{ABC})$, mikä johtui sekä kuivaaineen määrän että sen Mg-pitoisuuden vaihtelusta. CARPEnTERin (1957) tutkimuksissa peruna käytti magnesiumia paljon runsaammin, n. $90 \mathrm{~kg} / \mathrm{ha}$, mistä määrästä n. puolet oli mukuloissa. Tosin hänen myöhemmissä tutkimuksissaan 
perunan ottamat magnesiummäärät olivat osittain huomattavasti pienempiä, vaihdellen $14-105 \mathrm{~kg} / \mathrm{ha}$ (CARPENTER 1963). Mg-pitoisuudet varsinkin mukuloissa olivat hänen tutkimuksissaan huomattavasti korkeampia kuin selostettavassa tutkimuksessa. KUNKELin ym. (1973) tutkimuksissa mukulasadon sisältämä Mg-määrä oli $2.5 \mathrm{~kg} / 10 \mathrm{tn}$, eli samaa suuruusluokkaa kuin selostettavassa tutkimuksessa.

T y p pilannoit us vaikutti keskimäärin perunan magnesiumin käyttöön kuiva-aineen määrän suhteessa $(\mathrm{N}, \mathrm{AN}, \mathrm{BN}, \mathrm{ABN})$. Kuitenkin typpilannoitusta lisättäessä varsiston Mg-pitoisuus osittain aleni. Runsas typpilannoitus $\left(\mathrm{N}_{2}\right)$ alensi myös mukuloiden Mg-pitoisuutta kasvukauden lopulla, mikä osoittaa magnesiumin hidastunutta siirtymistä lehdistä mukuloihin (CN, ACN, BCN, Piirros 19).

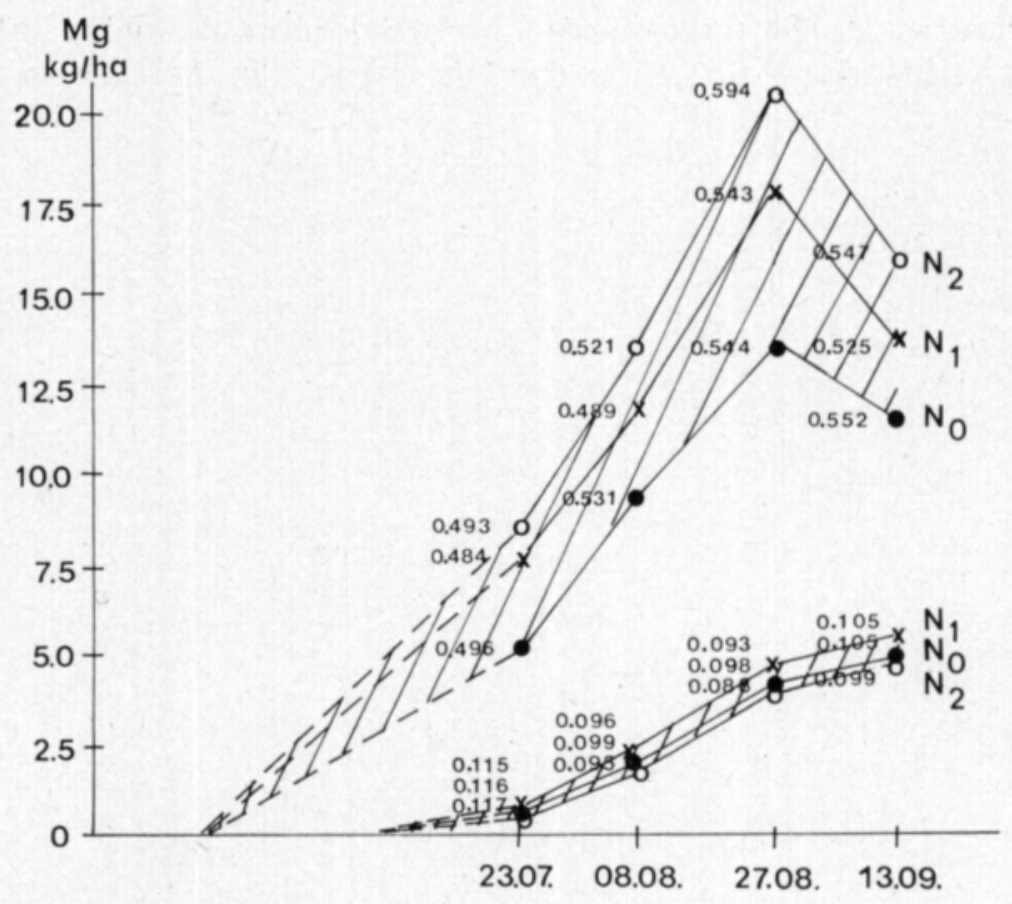

Piirros 19. N-lannoituksen vaikutus Pito-perunan magnesiumin käyttöön kasvukauden aikana.

Figure 19. Effect of $\mathrm{N}$ application on $\mathrm{Mg}$ uptake of Pito potato during the growing period.

Fosforilannoitus lisäsi perunan magnesiumin käyttöä yleensä samassa suhteessa kuin kuiva-ainesatoakin ( $\mathrm{P}, \mathrm{AP}, \mathrm{ABP}, \mathrm{BCP})$. Ainoastaan varsiston Mg-pitoisuus nousi v. 1967 ja laski v. 1968 fosforilannoitusta lisättäessä. Mukuloiden lievä Mg-pitoisuuden lasku fosforilannoitusta lisättäessä ei ollut joka vuosi merkitsevä (P, ACP). Hahlin ja JoHAnsson (1973) totesivat myös fosforilannoituksen lievästi alentavan mukuloiden $\mathrm{Mg}$-pitoisuutta, mutta lisäävän magnesiumin kokonaiskäyttöä.

Kalilannoitus vähensi varsiston magnesiumin saantia ja alensi 


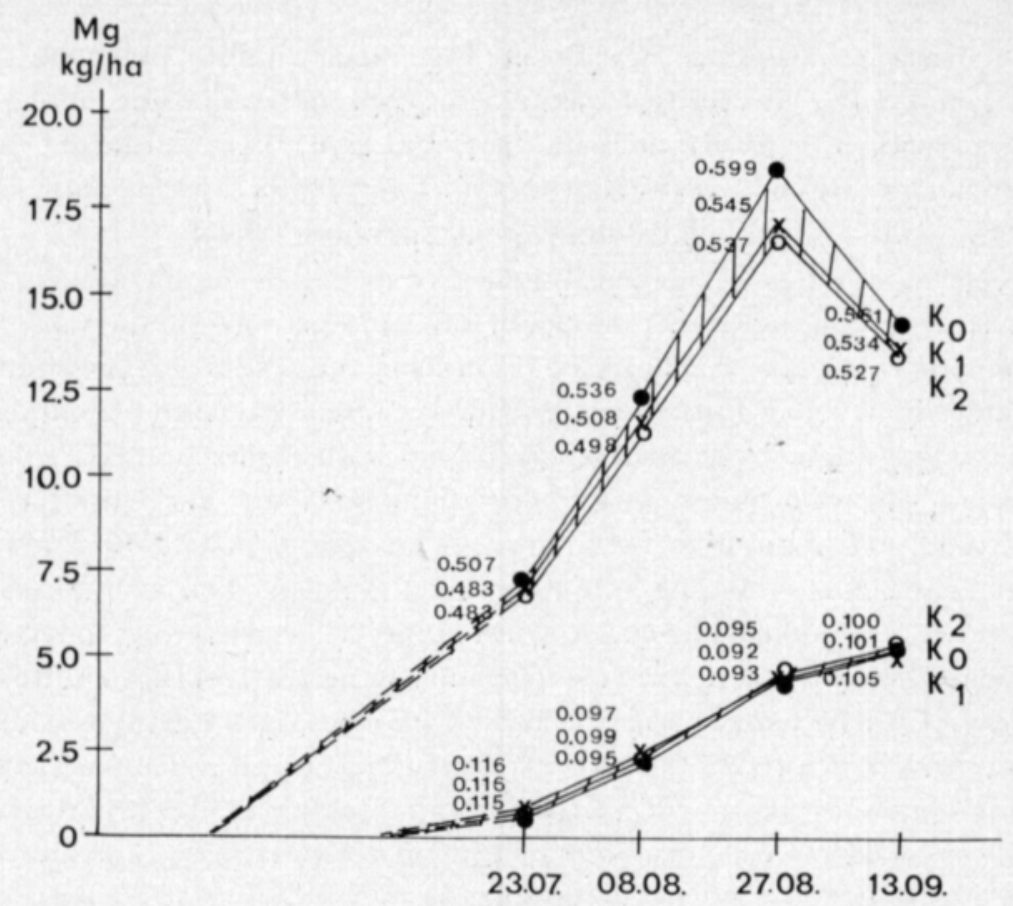

Piirros 20. K-lannoituksen vaikutus Pito-perunan magnesiumin käyttōön kasvukauden aikana. Figure 20. Effect of $K$ application on $M g$ uptake of Pito potato during the growing period.

myös sen kuiva-aineen Mg-pitoisuutta (K, CK, ACK, Piirros 20). Mukuloiden magnesiummääriin ja -pitoisuuksiin kalilannoituksen vaikutus oli vähäinen.

Typellä ja fosforilla oli yhdysvaikutuksia (NP, ANP, CNP). Vaikutukset noudattivat pääasiassa kuiva-aineen mukaista suuntaa. Fosforilannoituksella näytti kuitenkin olevan taipumusta estää mukuloiden Mg-pitoisuuden laskua runsasta typpilannoitusta käytettäessä. Yhdysvaikutus NPK osoitti samaa suuntaa kuin kalsium (vrt. sivu 12).

\section{Tulosten tarkastelua}

Edellä esitettyjä tuloksia arvosteltaessa on otettava huomioon, että ne on saatu vain yhdellä koepaikalla järjestetyistä kokeista. Sen vuoksi niissä on heijastumia koemaan ominaisuuksista.

Typpeä ja kaliumia Pito-peruna käytti runsaasti ja varsinkin kaliumin määrät olivat suuria verrattuna muihin tutkimuksiin (vrt. sivut 543). Kaliumin suhteen satotulokset viittaavatkin siihen, että suurin osa Pito-perunan käyttämästä lannoituksen kaliumista oli tarpeetonta tuhlakäyttöä. Näissä koeolosuhteissa fosforin saanti näytti olevan suhteellisen vaikeaa päätellen fosforilannoituksen hyvästä tehosta. Fosforilannoituksen lisääminen suurimmasta $\mathrm{P}_{2}$-määrästäkin olisi vielä saattanut johtaa mukuloiden kuiva-ainesadon lisääntymiseen. Osa fosforilannoituksen vaikutuksesta oli ilmeisesti fysiologista, kehitystä nopeuttavaa, mikä myöhäisen Pito-lajikkeen ollessa kysymyksessä oli mukulasadon kannalta etu (vrt. VARIS 1973c). 
Pito-perunan kalsiumin käyttö ei huomattavammin poikennut muista tutkimustuloksista. Kalsiumin määrä oli tosin niukanlainen, mutta todennäköisesti riittävä, sillä saadut mukulasadot eivät korreloituneet vuotuisiin kalsiummääriin eivätkä myöskään maan Ca-arvoihin, joten ainakaan tätä kautta ei voida osoittaa kalsiumin puutosilmiöitä.

Pito-perunan ottama magnesiummäärä oli myös niukanlainen, vaikka koemaassa viljavuusanalyysien mukaan oli runsaasti magnesiumia. Nimenomaan amerikkalaisissa tutkimuksissa herättää huomiota magnesiummäärien suuri vaihtelu. Useissa tapauksissa peruna on niissä käyttänyt moninkertaisen määrän magnesiumia verrattuna tässä saatuihin tuloksiin. Samalla myös mukuloiden Mg-pitoisuudet ovat olleet huomattavan korkeat (CARPENTER 1957 ja 1963). CARPENTERin tutkimuksissa oli esim. syksyllä 1955 perunoiden kuiva-aineen $\mathrm{K} / \mathrm{Ca}+\mathrm{Mg} 1.8$, v. 1956 8.8. samoissa koeolosuhteissa. Näin suuria kuiva-aineen koostumuksen vaihteluita ei yleensä ole todettu.

Näiden koetulosten perusteella ei liene aihetta periaatteellisiin muutoksiin käsiteltäessä perunan lannoitussuosituksia. Tätä koesarjaa koskevassa aikaisemmassa raportissa (VARIS 1973 c) on jo viitattu typen ja fosforin yhdysvaikutukseen sadon muodostuksen rytmiä säätelevänä tekijänä. Tässä tutkimuksessa $\mathrm{N} / \mathrm{P}$ oli keskimäärin $\mathrm{N}_{1} \mathrm{P}_{2}$-tasolla 9.1 , mitä lienee pidețtävä sopivana myöhäisille perunalajikkeille. Aikaisten lajikkeiden syyssatoa tuotettaessa N/P voinee nousta yli 10. Typpi-fosfori -suhteen säätely käytännössä tuottaa kuitenkin vaikeuksia sen takia, että perunan saatavissa olevan fosforin määrä on vaikea arvioida fosforin pidättymisen takia.

Toisen tärkeän ravinneryhmän muodostavat $\mathrm{K}, \mathrm{Ca}$ ja $\mathrm{Mg}$. Näiden välisiä suhteita kasvit pyrkivät myös säätelemään. Tässä tutkimuksessa $\mathrm{K} / \mathrm{Ca}+$ $\mathrm{Mg}$ oli kasvukauden aikana keskimäärin 3.9 ja $\mathrm{K} / \mathrm{Ca} 5.7$, mikä viittaa kalin yliannostukseen.

Koesarjassa todetut yhdysvaikutukset NK ja PK sekä NPK osoittavat myös NP- ja toisaalta KCaMg-ryhmän välisen kytkennän. Optimaalisia suhteita on koemaan runsaan kalipitoisuuden ja kalin heikon vaikutuksen vuoksi vaikea päätellä. $\mathrm{N}_{1} \mathrm{P}_{2}$-tasolla $\mathrm{K} / \mathrm{N}$ oli 1.7 ja $\mathrm{K} / \mathrm{P}$ 15.2. Nämä suhteet voivat kuitenkin olla tarpeettoman suuria koemaan ominaisuuksista johtuen.

Perunan lannoituksen oikean estimoinnin suurin vaikeus on maiden erilainen ravinnepitoisuus ja ravinteiden erilainen sitoutuminen sekä lisäksi sääolojen suuri vaikutus ravinteiden saantiin. Sen vuoksi tarvitaan runsaasti koetuloksia ja myös tilastoaineistoa, kun pyritään tarkennettuihin lannoitusohjeisiin maaperän ominaisuudet, lajike ja ilmasto-olot huomioon ottaen. Eräissä maissa, mm. Hollannissa ja Puolassa, tällaisia sovellutuksia on tosin jo olemassa. Tarkennettujen ohjeiden käyttöä varmentaa suuresti, jos vuotuista säiden aiheuttamaa satojen ja ravinteiden saannin suurta vaihtelua voidaan pienentää kastelulla.

\section{Yhteinveto}

Hankkijan kasvinjalostuslaitoksen Anttilan koetilalla selvitettiin vuosina 1967, 1968 ja 1970 Pito-perunan ravinteiden ottoa erilaista NPK-lannoitusta 
käytettäessä. N-määrät olivat 0,100 ja $200 \mathrm{~kg} / \mathrm{ha}, \mathrm{P}$-määrät 0,87 ja 174 $\mathrm{kg} / \mathrm{ha}$ ja K-määrät 0,166 ja $332 \mathrm{~kg} / \mathrm{ha}$.

Suurin mukuloiden kuiva-ainesato saatiin $\mathrm{N}_{1} \mathrm{P}_{2}$ lannoituksella, $5793 \mathrm{~kg} /$ ha. Tällöin kokonaiskuiva-ainesato nousi $8016 \mathrm{~kg}: \mathrm{aan} / \mathrm{ha}$. Mukulasadon kannalta optimilannoitusta $\mathrm{N}_{1} \mathrm{P}_{2}$ käytettäessä Pito-perunan ravinteiden kokonaiskäyttö oli (kg/ha) $129 \mathrm{~N}, 15 \mathrm{P}, 230 \mathrm{~K}, 42 \mathrm{Ca}$ ja $19 \mathrm{Mg}$. Mukulasadossa oli tällöin (kg/ha) $75 \mathrm{~N}, 11 \mathrm{P}, 122 \mathrm{~K}, 2.2 \mathrm{Ca}$ ja $6 \mathrm{Mg}$.

Typpilannoitus lisäsi typen käyttöä sekä lisäämällä kuiva-ainesatoa että nostamalla sekä varsiston että mukuloiden kuiva-aineen N-pitoisuutța. Typenkäytön lisäys kohdistui pääasiassa varsistoon. Fosforin kulutus lisääntyi myös, mutta sen suhteellinen saanti vaikeutui ja sen siirtyminen mukuloihin hidastui. Kaliumin käyttö lisääntyi ja samalla varsiston K-pitoisuus nousi. Kalsiumin käyttö lisääntyi, mutta samalla lehdistön Ca-pitoisuus laski. Magnesiumin käyttö lisääntyi myös, mutta lehdistön $\mathrm{Mg}$-pitoisuus aleni ja magnesiumin siirtyminen mukuloihin hidastui.

Fosforilannoitus lisäsi typen käyttöä kuiva-ainesadon nousun suhteessa. Typen siirtyminen mukuloihin nopeutui jossain määrin. Fosforin käyttö lisääntyi huomattavasṭi ja sekä varsiston että mukuloiden P-pitoisuudet nousivat. Fosforin siirtyminen mukuloihin myös nopeutui. Kalin kokonaiskäyttö lisääntyi, mutta sen suhteellinen osuus sekä varsistossa että mukuloissa pieneni kasvukauden lopulla. Kalsiumin käyttö lisääntyi kuiva-ainesadon nousun suhteessa ja sen siirtyminen mukuloihin nopeutui hiukan. Magnesiumin käyttö lisääntyi yleensä kuiva-ainesadon suhteessa.

Kalilannoitus ei vaikuttanut selvästi Pito-perunan typen käyttöön. Fosforin kokonaiskäyttö ei myöskään muuttunut, mutta sen saanti vaikeutui samanaikaisen runsaan N-lannoituksen kanssa. Kalin kokonaiskäyttö ei myöskään muuttunut, vaikka varsinkin varsiston $\mathrm{K}$-pitoisuus nousi. Kalsiumin käyttö ei muuttunut merkitsevästi, joskin suunta oli aleneva. Magnesiumin käyttö väheni ja lehdistön Mg-pitoisuus aleni. 
Benepal, P. S. 1967. Interrelations among plant nutrients, application levels on yield of potatoes. Amer. Potato J. 44: 187-194.

CArpenter, P. 1957. Mineral accumulation in potato plants. Maine Agric. Exp. St. Bull. 562: 1-23.

CARPEnter, P. N. 1963. Mineral accumulation in potato plants as affected by fertilizer application and potato variety. Maine Agric. Exp. St. Bull. 610:1-38.

DJurle, O. 1939. Potatisen. 117 p. Tukholma,

Ellala, A., Lannetta, I., Martilla, M., Myllylä, M., Pietilä, A., Seppãnen, E. \& Varis, E. 1971. Ruokaperunaopas I. 115 p. Helsinki.

Emilsson, B., Fernholm, H., Gustafsson, N. \& Ljungberg, G. 1968. Handledning för utsädesodlare av potatis i Norrland. 94 p. Uppsala.

Hahlin, M. \& Johansson, O. 1973. Fosfor- och kaliumgödsling till matpotatis. Lantbr.högsk. Medd. A, 192: 1-47.

Hunnius, W. 1972. Verwertungsgerechter Kartoffelbau. 184 p. Frankfurt.

Kunkel, R., Holstad, N. \& Russel, T. S. 1973. Mineral element content of potato plants and tubers vs. yields. Amer. Potato J. 50: 275 - 282 .

LÜddecke, F \& Borchmann, W, 1961. Nährstoffbedarf und Düngung. Die Kartoffel 683720. Berlin,

Salonen, T. 1962. Perunan viljelyopas. Kasvinsuoj.seur. Julk. 26: 1-55.

Sauli, J. O. 1943. Peruna. 128 p. Helsinki.

SePpänen, E \& VARIS, E. 1969. Perunanviljelyn opas. Kasvinsuoj.seur. Julk. 40: 1-72.

Tuorila, P. 1929. Untersuchungen über die chemische Zusammensetzung der Kartoffeln in Finnland. Suom. Suovilj.yhd. Tiet. Julk, 11: 1-73.

VARIS, E. 1973 a. The effects of increasing NPK rates on the yield and quality of the Pito potato. Acta Agr. Fenn. 128, 1: 1-23.

- -1973 b. NPK-lannoituksen vaikutus perunoiden kemialliseen koostumukseen. J. Scient. Agric. Soc. Finl. 45: 468-482.

- 1973 c. NPK-lannoituksen vaikutus Pito-perunan satotekijöihin. J. Scient. Agric. Soc. Finl. 45: 489-500. 